\title{
Development of a MetUM ( $v$ 11.1) and NEMO ( $v$ 3.6) coupled operational forecast model for the Maritime Continent - Part 1: Evaluation of ocean forecasts
}

\author{
Bijoy Thompson ${ }^{1}$, Claudio Sanchez ${ }^{2,3}$, Boon Chong Peter Heng ${ }^{3}$, Rajesh Kumar ${ }^{3}$, Jianyu Liu ${ }^{3}$, Xiang-Yu Huang ${ }^{3}$, and \\ Pavel Tkalich ${ }^{1}$ \\ ${ }^{1}$ Tropical Marine Science Institute, National University of Singapore, Singapore 119222, Singapore \\ ${ }^{2}$ Met Office, Exeter, EX1 3PB, United Kingdom \\ ${ }^{3}$ Centre for Climate Research Singapore, Meteorological Service Singapore, Singapore 537054, Singapore
}

Correspondence: Bijoy Thompson (bijoymet@gmail.com)

Received: 29 September 2020 - Discussion started: 19 October 2020

Revised: 15 December 2020 - Accepted: 29 December 2020 - Published: 23 February 2021

\begin{abstract}
This article describes the development and ocean forecast evaluation of an atmosphere-ocean coupled prediction system for the Maritime Continent (MC) domain, which includes the eastern Indian and western Pacific oceans. The coupled system comprises regional configurations of the atmospheric model MetUM and ocean model NEMO at a uniform horizontal resolution of $4.5 \mathrm{~km} \times 4.5 \mathrm{~km}$, coupled using the OASIS3-MCT libraries. The coupled model is run as a pre-operational forecast system from 1 to 31 October 2019. Hindcast simulations performed for the period 1 January 2014 to 30 September 2019, using the stand-alone ocean configuration, provided the initial condition to the coupled ocean model. This paper details the evaluations of ocean-only model hindcast and $6 \mathrm{~d}$ coupled ocean forecast simulations. Direct comparison of sea surface temperature (SST) and sea surface height (SSH) with analysis, as well as in situ observations, is performed for the ocean-only hindcast evaluation. For the evaluation of coupled ocean model, comparisons of ocean forecast for different forecast lead times with SST analysis and in situ observations of SSH, temperature, and salinity have been performed. Overall, the model forecast deviation of SST, SSH, and subsurface temperature and salinity fields relative to observation is within acceptable error limits of operational forecast models. Typical runtimes of the daily forecast simulations are found to be suitable for the operational forecast applications.
\end{abstract}

\section{Introduction}

Dynamical processes and flux exchanges between Earth system components are better represented in coupled modelling systems rather than the single-component models (e.g. Meehl, 1990). Hence, coupled models, particularly with dynamically interactive atmosphere, ocean, land surface, and sea ice models, are increasingly employed for climate research as well as operational forecast applications (e.g. Miller et al., 2017; Lewis et al., 2018, 2019a). The atmosphere and ocean are two major components of the Earth's climate system, and interactions between these two systems are key drivers of climate and weather. In the past, efforts toward the development of atmosphere-ocean coupled models were largely constrained by their high computational requirements, limited understanding of air-sea coupled processes, and lower computational efficiency (Meehl, 1990). During the last 3 decades, there have been significant advancements in the computational power of supercomputers and the computational efficiency of atmosphere-ocean circulation models. Presently, global atmosphere-ocean-wave-land surfacesea ice coupled operational forecasts are available at spatial resolutions of $0.1^{\circ}$ in the Integrated Forecast Systems (IFS) developed by the European Centre for Medium Range Weather Forecasting (ECMWF) to $0.25^{\circ}$ in the Global Forecast System (GFS) developed by the National Center for Environmental Prediction (NCEP). Moreover, the accessibility of high-performance computers (HPCs) to researchers has considerably increased in the last decade. Several regional 


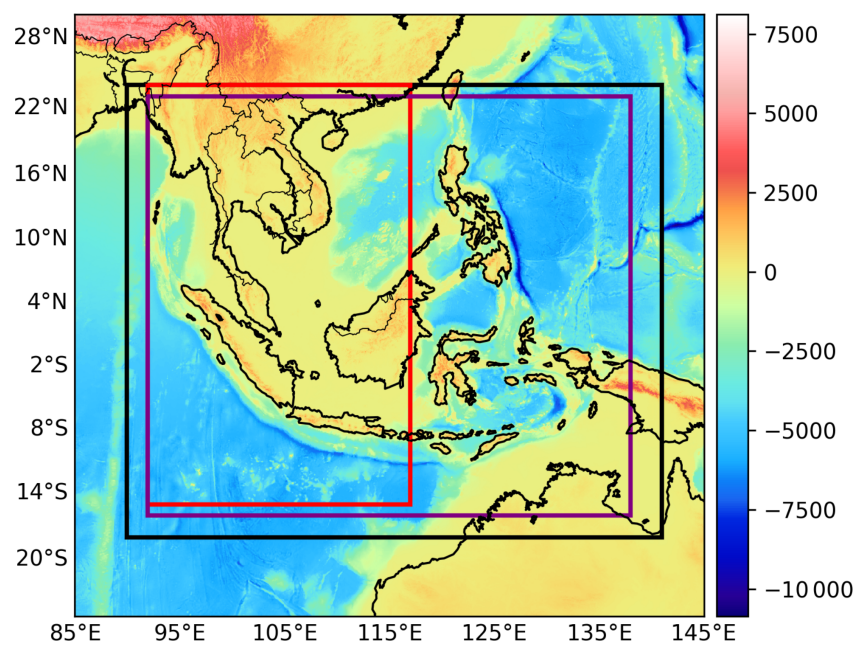

Figure 1. Bathymetry and orography (in metres) of the Maritime Continent from GEBCO 2014 data: MC coupled model domain (black box), western Maritime Continent domain in Thompson et al. (2018) (red box), and domain used for ocean forecast evaluation in present study (purple box).

and global atmosphere-ocean coupled modelling systems have been developed worldwide during this period (see reviews by Giorgi and Gutowsky, 2015, and Xue et al., 2020).

The tropical region lying between the eastern Indian Ocean and western Pacific Ocean, encompassing the Malay Peninsula, Philippine Archipelago, Indonesian Archipelago, and surrounding oceanic and island region is generally referred to as the Maritime Continent (MC). This region is characterised by complex orography and shallow seas interconnected by numerous straits (Fig. 1). The MC region is characterised by strong atmosphere-ocean coupled processes across multiple timescales. The El Niño-Southern Oscillation (Bjerknes, 1969) and the Indian Ocean Dipole-Zonal Mode (Saji et al., 1999; Webster et al., 1999) represent two dominant climate modes of variability that influence the MC on inter-annual timescales. Meanwhile, the monsoons and Madden Julian Oscillation (MJO, Madden and Julian, 1994) manifest the coupled processes over the MC in seasonal and intra-seasonal scales, respectively. Because of its geographical location in the middle of the Indo-Pacific warm pool and in the ascending branch of global atmospheric Walker circulation, the MC has been identified as an area of climatic importance both in regional and global environments (Neale and Slingo, 2003; Qu et al., 2005).

The development of regional coupled models is mainly driven by the idea that by resolving fine-scale orographic, ocean circulation, and coastal ocean features, a more accurate representation of atmosphere-ocean dynamics and coupled processes can be achieved. The prediction of atmospheric and oceanic variables over the $\mathrm{MC}$ is challenging because of its complex geography, strong air-sea coupling, and remote ocean influences. Earlier studies suggested that the accuracy of atmospheric and ocean hindcast and forecast significantly improves when the simulations are performed using coupled models (Xue et al., 2014; Thompson et al., 2018; Lewis et al., 2019a). There have been a few coupled modelling studies over the MC focusing on the climate and weather research or short-range atmosphere-ocean forecasting (e.g. Aldrian et al., 2005; Wei et al., 2014; Li et al., 2017; Thompson et al., 2018). Recently, Xue et al. (2020) presented a review of atmosphere-ocean coupled modelling studies over the MC region.

Besides coupling, the model skill in simulating atmosphere and ocean state shows a strong relation to the grid resolution also (e.g. Li et al., 2017). Local mesoscale processes (e.g. land and sea breezes) also play an important role in the adequate simulation of upscale processes such as the MJO (Birch et al., 2016). Convection plays a fundamental role, either locally or embedded in bigger envelopes such as the MJO, influencing the diurnal cycle of precipitation and moving squall lines (Love et al., 2011). Therefore, the simulation of weather and climate processes over the MC requires sufficient resolution to resolve these scales and their interactions. Generally, a horizontal resolution of approx. $4 \mathrm{~km}$, so-called convection permitting, has been effective in representing fine-scale processes over the MC (Love et al., 2011; Birch et al., 2014, 2016; Vincent and Lane, 2017). The first attempt towards the development of a convection-permitting atmosphere-ocean coupled model over the MC was undertaken by Thompson et al. (2018, hereafter T18). T18 used a regional version of the UK Met Office Unified Model (MetUM) atmospheric model and Nucleus for European Modelling of the Ocean (NEMO) ocean model configured for the western MC (WMC). For simplicity, the WMC coupled model configuration used in $\mathrm{T} 18$ is referred to as $\mathrm{WMC}_{\mathrm{a}}$ hereafter. The atmosphere and ocean components of $\mathrm{WMC}_{\mathrm{ao}}$ were configured for the same domain and similar horizontal resolution of $4.5 \mathrm{~km} \times 4.5 \mathrm{~km}$ (Fig. 1). The model resolution is fine enough to represent the complex coastal geography, ocean bathymetry at shallow oceans and straits, and orographic features, such as mountain ranges, with enormous influences in local weather (e.g. Bukit Barisan in Sumatra or the Sierra Madre in Luzon).

Work to develop and perform a first-hand evaluation of the $\mathrm{WMC}_{\mathrm{ao}}$, described in $\mathrm{T} 18$, was a preliminary step aimed to establish a high-resolution atmosphere-ocean coupled model focusing on the Southeast Asian region for both operational forecasts and climate research applications. Since the overall objective of the development was to simulate both atmospheric and oceanic variables, the coupling has provided a better consistency between the atmospheric conditions and that of the ocean underneath rather than employing standalone models. The case studies conducted as part of the $\mathrm{WMC}_{\mathrm{ao}}$ evaluation suggested that the zonal extent of the domain might not be sufficient for an accurate prediction of weather events such as cold surges or typhoons. For instance, cyclogenesis inside the South China Sea (SCS) is 
relatively low and most of the cyclones and typhoons that appear over the SCS originated in the northwestern Pacific Ocean (e.g. Ling et al., 2011). The northern Pacific Ocean region between $100^{\circ} \mathrm{E}$ and $180^{\circ} \mathrm{E} / \mathrm{W}$ is the most active tropical cyclone basin on Earth and it accounts for about onethird of the world's tropical cyclones annually (e.g. Lee et al., 2020). Hence, rather than internally coupled dynamics, the predicted track and typhoon characteristics are dominantly driven by the lateral boundary conditions ( $\mathrm{LBCs}$ ) in $\mathrm{WMC}_{\mathrm{ao}}$. Similarly, the simulation of MJO- and cold-surge-related weather parameters may also be heavily influenced by LBCs. Hence, to address the issues encountered in T18 and incorporate the latest model scientific developments, the present study aims to bring several key upgrades to the $\mathrm{WMC}_{\mathrm{ao}}$ configuration, and test its feasibility in operational forecast application. The main updates to the coupled modelling system include extending the eastern boundary of the model domain to the western Pacific Ocean, upgrading MetUM to the latest science configuration, and incorporating tide boundary forcing into the NEMO.

This study presents details of the atmosphere-ocean coupled prediction system developed for the MC and an evaluation of the ocean forecast from the system using a $6 \mathrm{~d}$ preoperational forecast for October 2019. Following the method employed in many earlier coupled modelling studies (e.g. Li et al., 2014; Lewis et al., 2018), the evaluation of $\mathrm{WMC}_{\mathrm{ao}}$ in T18 has been performed by using short case study simulations of selected weather events spanning over $5 \mathrm{~d}$. In the present study, instead of case studies, we assess surface and subsurface oceanic variables predicted by the coupled system across different forecast lead times.

The next section of this paper presents an overview of the model setup, including a brief description of the model domain, atmospheric, ocean, and coupled model configurations. A brief discussion of the pre-operational forecast system setup is also presented. Section 3 provides the details of datasets used for the atmosphere and ocean model forcing and evaluation. Section 4 presents an assessment of the sea surface variables simulated by the stand-alone ocean model and both surface and subsurface ocean forecasts delivered by the MC coupled model. Finally, Sect. 5 summarises the results obtained from the study and suggests future developments.

\section{Model setup}

\subsection{Model domain}

The model domain extends from $18^{\circ} \mathrm{S}$ to $24^{\circ} \mathrm{N}$ and 92 to $141^{\circ} \mathrm{E}$ (Fig. 1) on a regular latitude-longitude grid that covers most of the tropical regions of eastern Indian Ocean and western Pacific Ocean. The deepest oceanic trench on Earth, known as the Mariana Trench, is located in the northwestern Pacific Ocean. The crescent-shaped trench is po- sitioned roughly between $10^{\circ} \mathrm{N}, 140^{\circ} \mathrm{E}$ and $60^{\circ} \mathrm{N}, 150^{\circ} \mathrm{E}$ (Gvirtzman and Stern, 2004). The model eastern boundary is limited to $141^{\circ} \mathrm{E}$ to avoid numerical instabilities that may arise due to steep bathymetric slopes such as the Mariana Trench. Both the atmospheric and ocean components of the coupled system are selected to have the same domain. The horizontal resolution of the MC coupled model remained the same $(4.5 \mathrm{~km} \times 4.5 \mathrm{~km})$ as that of the $\mathrm{WMC}_{\mathrm{ao}}$. The MC atmosphere-ocean coupled model configuration is referred to as $\mathrm{MC}_{\mathrm{ao}}$ in this paper.

\subsection{Atmospheric model}

The atmospheric component of T18 has been improved to employ the SINGV v5 science configuration described in Huang et al. (2019), which is similar to the Regional Atmosphere and Land $\mathrm{v} 1$ in the Tropics (RAL1-T) configuration of MetUM (version 11.1) described in Bush et al. (2020). The model has been employed operationally by the Meteorological Service of Singapore since 2019 at a higher resolution $(1.5 \mathrm{~km})$ for the region $6^{\circ} \mathrm{S}$ to $8^{\circ} \mathrm{N}, 95^{\circ} \mathrm{E}$ to $109^{\circ} \mathrm{E}$ and is referenced in the literature as SINGV. The key differences of $\mathrm{MC}_{\mathrm{ao}}$ atmospheric model component to T18 are as follows.

- Lateral boundary conditions are provided at 3-hourly frequency from the deterministic ECMWF forecasts instead of the MetUM global deterministic model. This change has led to a significant increase in precipitation skill scores across all spatial scales and precipitation thresholds in SINGV (Huang et al., 2019).

- The model uses a prognostic cloud fraction and prognostic condensate scheme (PC2, Wilson et al., 2008) instead of the diagnostic scheme of Smith (1990). This change helped to reduce the occurrence of spurious convection with very high rainfall rates and resulted in a better organisation of convection, as shown in Dipankar et al. (2020).

The rest of the model formulations are similar to T18 and the SINGV configuration described in Huang et al. (2019). The main characteristics of the model are summarised below.

- The dynamical core is the non-hydrostatic semiLagrangian and semi-implicit Even Newer Dynamics for the General Atmospheric Modelling of the Environment (ENDGAME, Wood et al., 2014), with an Arakawa-C staggered grid. The model time step is $120 \mathrm{~s}$.

- The model has a terrain-following vertical coordinate with a resolution of 80 levels and a top lid at $38.5 \mathrm{~km}$. The vertical resolution is $5 \mathrm{~m}$ at the boundary layer and $1.45 \mathrm{~km}$ below the model top, similar to the SINGV configuration.

- The boundary layer parameterisation is based on a blending between the one-dimensional scheme of Lock 
et al. (2001) and the three-dimensional SmagorinskyLilly scheme (Lilly, 1962); this blending is described in Boutle et al. (2014).

- The microphysics scheme is based on Wilson and Ballard (1999) with prognostic rain formulation and improved particle size distribution for rain as in Abel and Boutle (2012).

- The radiation scheme is based on the Edwards and Slingo (1996) scheme, with six bands in the shortwave and nine bands in the longwave (Manners et al., 2011).

- The Joint UK Land Environment Simulator (JULES, Best et al., 2011) land surface scheme with 9 surface fraction types is also used.

- The moist conservation scheme is used as described in Aranami et al. (2015).

The Atmospheric component of the $\mathrm{MC}_{\mathrm{ao}}$ employed in this study is referred to as $\mathrm{MCA}_{\mathrm{ao}}$ hereafter.

\subsection{Ocean model}

A regional version of Océan Parallélisé ocean engine within the NEMO (version 3.6_stable, revision 6232, Madec et al., 2016) framework is employed as the oceanic component of the $\mathrm{MC}_{\mathrm{ao}}$. NEMO is a primitive-equation, hydrostatic, Boussinesq ocean model extensively used in climate and operational forecast applications. The $\mathrm{MC}_{\mathrm{ao}}$ ocean configuration shares many features of its predecessor, $\mathrm{WMC}_{\mathrm{ao}}$. Hence, only key features of the NEMO and main updates of $\mathrm{MC}_{\mathrm{ao}}$ configuration are discussed here.

The model horizontal grid is in orthogonal curvilinear coordinates, with Arakawa-C grid staggering. The bathymetry of $\mathrm{MC}_{\mathrm{ao}}$ is based on the General bathymetric Chart of the Oceans (GEBCO2014) $30 \mathrm{arcsec}$ data (https://www.gebco.net/data_and_products/historical_ data_sets/\#gebco_2014, last access: 9 December 2020). The model has 51 vertical levels in terrain-following coordinate system and uses the stretching function by Siddorn and Furner (2013). The stretching function maintains a nearuniform surface cell thickness $(\leq 1 \mathrm{~m})$ and hence ensures the consistent exchange of air-sea fluxes over the domain, which is critical in the atmosphere-ocean coupling. Non-linear free surface following the variable volume layer formulation by Levier et al. (2007) is used for model free surface computation. The ocean model configurations used in our study have baroclinic and barotropic time steps of 120 and $8 \mathrm{~s}$, respectively.

The generic length scale (GLS) turbulence model (Umlauf and Burchard, 2013) with K- $\varepsilon$ turbulent closure scheme and the stability function from Canuto et al. (2001) are used to compute the turbulent viscosities and diffusivities. Background vertical eddy viscosity and eddy diffusivity coefficients are set to a lower value of $1.2 \times 10^{-6}$ in $\mathrm{MC}_{\mathrm{ao}}$, whereas these coefficients were $1.2 \times 10^{-4}$ and $1.2 \times 10^{-5}$, respectively, in the $\mathrm{WMC}_{\mathrm{ao}}$. Additional vertical mixing resulting from internal tide breaking is parameterised in the model as proposed by St. Laurent et al. (2002). Both energy- and enstrophy-conserving schemes is used for the momentum advection. For lateral tracer diffusion, the Laplacian operator along geopotential levels with a coefficient of $20 \mathrm{~m}^{2} \mathrm{~s}^{-1}$ is used, while iso-level bi-Laplacian viscosity with a coefficient of $-6 \times 10^{7} \mathrm{~m}^{2} \mathrm{~s}^{-1}$ is applied for the momentum mixing. An implicit form of non-linear parameterisation with a log layer formulation is used for the bottom drag coefficient computation. The minimum and maximum of the drag coefficient are set to 0.0001 and 0.15 , respectively.

At the lateral open-ocean boundaries, the flow relaxation scheme (FRS, Davies, 1976) is applied for the tracers and baroclinic velocities, while Flather boundary condition (Flather, 1976) is used for the sea surface height (SSH) and barotropic velocities. One of the key updates to $\mathrm{MC}_{\mathrm{ao}}$ is the implementation of tide forcing at the lateral boundaries and tide potential at the ocean surface. Due to certain numerical issues, the tide-related forcings are not included in the $\mathrm{WMC}_{\mathrm{ao}}$. The tidal elevations and currents from finiteelement solutions (FES2014b) data have been used for providing the tidal harmonics at the lateral boundaries (Lyard et al., 2006). A total of 15 major tidal constituents (Q1, O1, P1, S1, K1, 2N2, Mu2, Nu2, N2, M2, L2, T2, S2, K2, and M4) are included in the boundary forcing.

Both coupled and uncoupled ocean model configurations are employed in the study. For uncoupled simulations, the air-sea heat fluxes are estimated using the Common Oceanice Reference Experiment (CORE) bulk formulae (Large and Yeager, 2004). However, a direct flux formulation is used in the coupled ocean model. Monthly runoff climatology from Dai and Trenberth (2002) and chlorophyll monthly climatology from SeaWiFS satellite observation are provided as runoff forcing and to compute light absorption coefficients, respectively, in all ocean configurations. The red-blue-green (RGB) scheme is used to calculate the penetration of shortwave radiation into the ocean (Lengaigne et al., 2007). Identical to $\mathrm{WMC}_{\mathrm{ao}}$, the fraction of solar radiation absorbed at the surface layer is defined to be $56 \%$ of the downward component. Mean sea level pressure (MSLP) forcing is included in the surface boundary forcing to take account of the inverse barometric effect on SSH.

The uncoupled and coupled ocean model configurations employed in this study are referred to as $\mathrm{MCO}$ and $\mathrm{MCO}_{\mathrm{ao}}$, respectively.

\subsection{Coupled configuration}

The exchange of fluxes between the atmosphere and ocean models is achieved through the Ocean Atmosphere Sea Ice Soil coupler (version 3.3) interfaced with the Model Coupling Toolkit (OASIS3-MCT) libraries (Valcke, 2013). The Earth System Modelling Framework (ESMF) regrid tools are 
used to generate the interpolation weights for the remapping of exchange fields. The coupling occurs at hourly frequency, and hourly mean fields are exchanged. Since a direct flux formulation is implemented, the heat fluxes computed using the Monin-Obukhov similarity theory is exchanged from the atmosphere to the ocean model. The sea surface temperature (SST) and zonal and meridional surface current fields are sent from the ocean to the atmosphere model. The variables exchanged from atmosphere to the ocean include nonsolar heat flux, net shortwave radiation, liquid precipitation, net evaporation, and zonal and meridional wind stress. Due to numerical issues, MSLP exchange from the atmosphere is not enabled in the $\mathrm{MC}_{\mathrm{ao}}$. Instead, it is supplied from an external data source to the ocean model. The MSLP from ECMWF IFS data have been used in our coupled forecast simulations.

\subsection{Model initialisation and forcing}

To assess the performance of the ocean model and provide initial condition to the $\mathrm{MCO}_{\mathrm{ao}}$, a 69-month hindcast simulation is performed with MCO for the period 1 January 2014 to 30 September 2019. The MCO was initialised in 1 January 2014 using temperature, salinity, zonal and meridional currents, and SSH derived from Mercator global ocean reanalysis. The lateral boundary condition for the hindcast simulation is also obtained from the same ocean reanalysis data. The daily mean of temperature, salinity, baroclinic and barotropic velocities, and SSH are included in the lateral boundary forcing. Ocean surface is forced by ECMWF Reanalysis 5 (ERA5) during the period from 1 January 2014 to 30 June 2019. Downward shortwave and longwave radiation at the ocean surface; total precipitation; MSLP; and $10 \mathrm{~m}$ wind velocities, air temperature, and specific humidity fields are included in the forcing file. Since there was a delay of about 2-3 months in the release of ERA5 data during the time of model development, the MCO is forced by the 6-hourly ECMWF IFS analysis fields from 1 July 2019 to the start of $\mathrm{MC}_{\mathrm{ao}}$ pre-operational forecast run on 1 October 2019 (Fig. 2a). As the atmospheric adjustments are subdaily, no spin-up or hindcast simulations are performed for the $\mathrm{MCA}_{\mathrm{ao}}$

A schematic of the atmosphere-ocean coupled system used in the pre-operational forecast is shown in Fig. 2b. In the coupled prediction system, the $\mathrm{MCA}_{\mathrm{ao}}$ is initialised daily at 00:00 Z UTC from the ECMWF IFS analysis. MCO run for the previous day (T0 minus 1), forced by 6-hourly ECMWF IFS analysis at the surface and the daily mean of updated Mercator ocean forecast as the LBC, provides the initial condition to $\mathrm{MCO}_{\mathrm{ao}}$. Since it is driven by analysed (or updated) surface (lateral) boundary conditions, the $\mathrm{MCO}$ provides an updated initial condition to the $\mathrm{MCO}_{\mathrm{ao}}$ daily. The $\mathrm{MC}_{\mathrm{ao}}$ forecast run is driven by LBC from 3-hourly ECMWF IFS forecasts in the atmosphere and daily Mercator forecasts in the ocean. Since the MSLP from $\mathrm{MCA}_{\mathrm{ao}}$ is not incorporated in (a) MCO

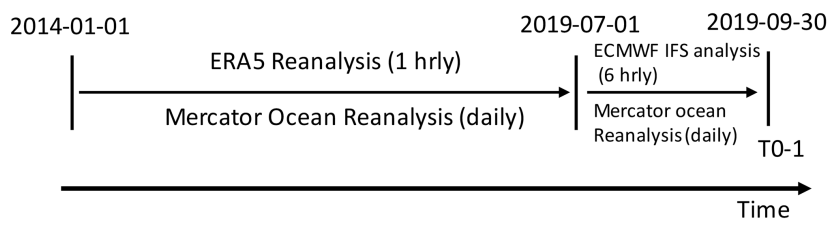

(b) $\mathrm{MC}_{\mathrm{ao}}$

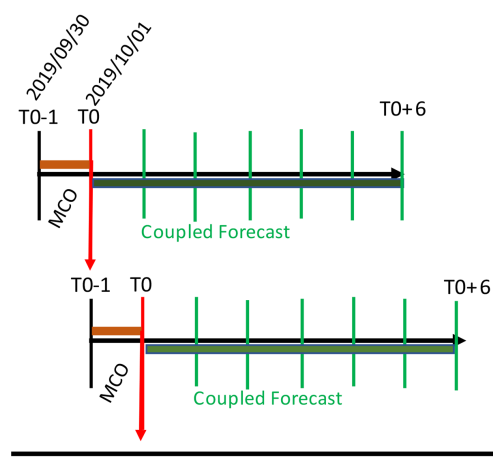

Forecast on 2019/10/01

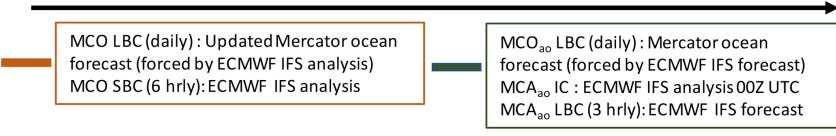

Figure 2. Schematic of modelling systems used in the study: (a) MC ocean-only model (MCO) hindcast and (b) MC atmosphereocean coupled forecast model $\left(\mathrm{MC}_{\mathrm{ao}}\right)$. $\mathrm{MCO}_{\mathrm{ao}}$ stands for the $\mathrm{MC}$ coupled ocean model, $\mathrm{MCA}_{\mathrm{ao}}$ stand for the MC coupled atmospheric model, LBC stands for the lateral boundary condition, SBC stands for the surface boundary condition, IC stands for the initial condition.

$\mathrm{MCO}_{\mathrm{ao}}$, 3-hourly EMCWF IFS forecast data are supplied to the model.

\subsection{Pre-operational forecast setup}

The atmosphere-ocean coupled forecast model ran as a preoperational forecast system from 1 to 31 October 2019 at the Cray XC-40 HPC located in the Center for Climate Research Singapore (CCRS), Singapore. The forecast system includes all necessary programs and scripts for the pre-processing of atmospheric and oceanic variables to their respective model grids. The forecast system is scheduled to initialise the forecasts daily at 13:00 UTC, and simulations are completed by $\sim$ 18:40 UTC. Summary of HPC resources usage and typical runtimes for daily forecast simulations are shown in Table 1 . To minimise the output size, only basic oceanic and atmospheric variables are included in the output. The forecast from $\mathrm{MCO}_{\mathrm{ao}}$ includes instantaneous $\mathrm{SSH}$; hourly averaged sea surface temperature, sea surface salinity, and surface current velocities; and the daily mean of ocean temperature, salinity, and ocean currents. Further, to test the feasibility of the coupled forecast system for operational purpose, we have conducted simulations with increased computational resources. Test simulations showed that by increas- 
ing the computational resources to 81 nodes (2916 cores), the total runtime has been reduced to $\sim 140 \mathrm{~min}$. This suggests a near-linear reduction in total runtime with an increase in computation nodes.

\section{Data}

A brief description of the reanalysis, forecast, and observational datasets used for the model initialisation, forcing, and evaluation is presented in this section.

\subsection{Model initialisation and forcing}

ERA5 is a climate reanalysis produced by the ECMWF providing hourly estimates of many atmospheric, land, and oceanic fields (Hersbach et al., 2020). Currently, it covers the period from 1979 to within $5 \mathrm{~d}$ of the present, and its horizontal resolution is approx. $30 \mathrm{~km}$. The reanalysis is produced using 4D-Var assimilation of the ECMWF Integrated Forecast System (IFS). ERA5 combines vast amounts of historical observations into global estimates using advanced modelling and data assimilation systems. The data are freely available through the data server https://cds.climate. copernicus.eu/ (last access: 20 November 2020).

ECMWF IFS is a global weather prediction system comprising a spectral atmospheric model, ocean wave model, ocean model, and land surface model coupled to a 4DVar data assimilation system. IFS medium-range weather forecasts are available up to $10 \mathrm{~d}$ at a horizontal resolution of $0.1^{\circ}$. In addition, the atmospheric analysis fields are provided four times daily for the forecast base times 00:00, 06:00, 12:00, and 18:00 UTC. The data are available to registered users from https://www.ecmwf.int/en/forecasts/ datasets/ (last access: 20 November 2019).

Mercator global ocean reanalysis and forecast provides oceanic variables with $0.0833^{\circ}$ horizontal resolution (Lellouche et al., 2018). The system uses NEMO v3.1 with 50 vertical $z$ levels ranging from zero to $5500 \mathrm{~m}$ and forced by the ECMWF IFS meteorological variables. The assimilation and forecast product includes the daily mean of temperature, salinity, currents from top to bottom over the global ocean, and SSH. The data are freely available from https: //marine.copernicus.eu/ (last access: 20 December 2020).

The tidal heights and currents computed from the global tide model finite-element solution (FES2014b) is used as the tidal forcing in the model. FES2014 is based on the resolution of the shallow water hydrodynamic equations (T-UGO model) in a spectral configuration and using a global finite-element mesh with increasing resolution in coastal and shallow waters regions (Lyard et al., 2006). The database is distributed on a global $0.0625^{\circ} \times 0.0625^{\circ}$ grid. Data are produced by assimilating long-term altimetry data (Topex, Poseidon, Jason-1, Jason-2, TPN-J1N, and ERS-1, ERS-2, ENVISAT) and tidal gauges through an improved representer assimilation method. Tidal heights and currents of 32 tidal constituents are available. The data are freely available through http://www.aviso.altimetry.fr/en/ data/products/auxiliary-products/global-tide-fes.html (last access: 25 November 2020).

\subsection{Model evaluation}

The CORIOLIS data service provides quality-controlled in situ data in real-time and delayed modes over the global ocean. The data include temperature and salinity profiles and time series from profiling floats, expendable bathythermographs (XBTs), thermo-salinographs (TSGs), and drifting buoys. The data are freely available from http: //www.coriolis.eu.org/Data-Products/ (last access: 6 November 2020).

The Operational Sea Surface Temperature and Sea Ice Analysis (OSTIA) SST is produced daily on an operational basis at the UK Met Office using optimal interpolation on a global $0.054^{\circ} \times 0.054^{\circ}$ grid. The product assimilates satellite data including advanced Very-High Resolution Radiometer, Spinning Enhanced Visible and Infrared imager, Geostationary Operational Environmental Satellite Imager, Infrared Atmospheric Sounding Interferometer, and Tropical Rainfall Measuring Mission Microwave imager data and in situ data from ships and drifting and moored buoys (Donlon et al., 2012). SST data at every grid point are accompanied by an uncertainty estimate, known as an analysis error, and an optimal interpolation approach is employed to produce this estimate. The data are freely available from https: //marine.copernicus.eu/ (last access: 22 December 2020).

The University of Hawaii Sea Level Center (UHSLC) offers quality-controlled tide gauge (TG) sea level observations over the global ocean as fast-delivery (FD, 1-2-month delay) and research-quality (RQ, 1-2-year delay) data at hourly and daily resolution (Caldwell et al., 2015). The data are freely available from http://uhslc.soest.hawaii.edu/data/ (last access: 23 November 2020).

\section{Results and discussion}

An evaluation of the MCO hindcast and $\mathrm{MCO}_{\mathrm{ao}}$ forecast simulations are presented in this section of the paper. Direct comparison of model simulations with observation or analysis data has been performed. Based on the availability of in situ or satellite observation at the time of data analysis, only a few variables are selected for assessing the model performance. In addition, to maintain consistency between the evaluation of hindcast and forecast simulations, analyses of the same set of variables and observation data have been performed where possible. Oceanic variables employed for the evaluation are SST, SSH, and the subsurface temperature and salinity. 
Table 1. Summary of HPC resources usage and typical runtimes.

\begin{tabular}{lllc}
\hline Configuration & $\begin{array}{l}\text { Uncoupled ocean } \\
(\mathrm{MCO})\end{array}$ & $\begin{array}{l}\text { Coupled atmosphere } \\
\left(\mathrm{MCA}_{\mathrm{ao}}\right)\end{array}$ & $\begin{array}{l}\text { Coupled ocean } \\
\left(\mathrm{MCO}_{\mathrm{ao}}\right)\end{array}$ \\
\hline Total nodes (cores) & $16(576)$ & $24(864)$ & \multicolumn{2}{c}{$4(144)$} \\
Daily runtime & $6.5 \mathrm{~min}$ & \multicolumn{2}{c}{$330 \mathrm{~min}$} \\
Core hours & 3.9 & \multicolumn{2}{c}{198} \\
Flume/IO (node) & & \multicolumn{2}{c}{1} \\
\hline
\end{tabular}

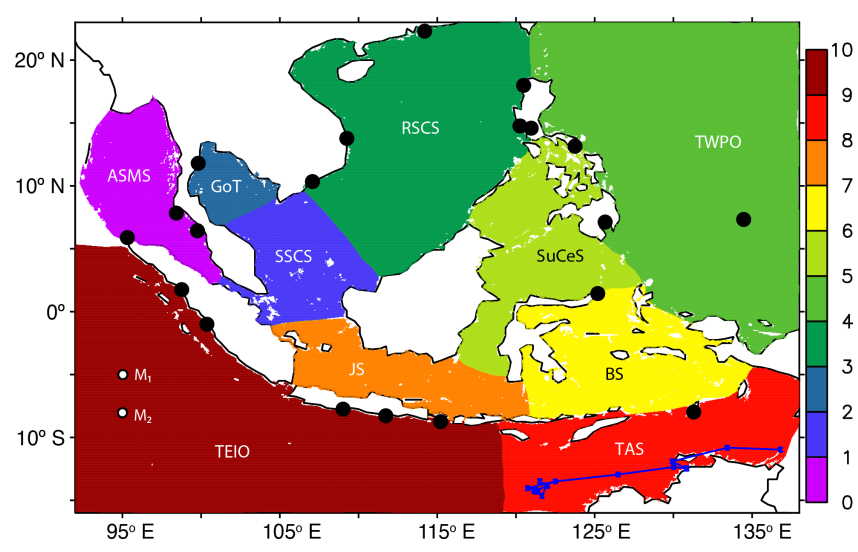

Figure 3. Domain used for hindcast and forecast evaluation with sub-regions defined in the study: (1) Andaman Sea-Malacca Strait (ASMS), (2) southern South China Sea (SSCS), (3) Gulf of Thailand (GoT), (4) the rest of the South China Sea (RSCS), (5) the tropical western Pacific Ocean (TWPO), (6) Sulu-Celebes seas (SuCeS), (7) Banda Sea (BS), (8) Java Sea (JS), (9) Timor-Arafura seas (TAS), and (10) the tropical eastern Indian Ocean (TEIO). The Bay of Bengal region (north of $5^{\circ} \mathrm{N}$, west of $92^{\circ} \mathrm{E}$ ) is excluded when analysis is performed for different sub-regions. The blue line in the TAS indicates the TSG observation track. The locations of tide gauges are shown as black circles. Moored buoy locations $\mathrm{M}_{1}$ $\left(5^{\circ} \mathrm{S}, 95^{\circ} \mathrm{E}\right)$ and $\mathrm{M}_{2}\left(8^{\circ} \mathrm{S}, 95^{\circ} \mathrm{E}\right)$ are also shown.

Model hindcasts and forecasts over the region $16^{\circ} \mathrm{S}$ to $23^{\circ} \mathrm{N}$ and 92 to $138^{\circ} \mathrm{E}$ and defined as the analysis domain (Figs. 1 and 3), is further used for the analysis. The MC model domain includes oceanic basins with different geographical and climatological characteristics. For the evaluation purpose, we have divided the analysis-domain into 10 sub-regions based on their geographical distribution (Fig. 3). These sub-regions are the (1) Andaman Sea-Malacca Strait (ASMS), (2) southern South China Sea (SSCS), (3) Gulf of Thailand (GoT), (4) the rest of the South China Sea (RSCS), (5) the tropical western Pacific Ocean (TWPO), (6) SuluCelebes seas (SuCeS), (7) Banda Sea (BS), (8) Java Sea (JS), (9) Timor-Arafura seas (TAS), and (10) the tropical eastern Indian Ocean (TEIO).

\subsection{Ocean hindcast}

An overall assessment of the ocean model hindcast simulation is carried out to understand the realism of the ocean initial condition for the coupled forecasts, particularly at the ocean surface where the exchange of fluxes between the atmosphere and ocean takes place. Though the hindcast simulations encompass from 1 January 2014 to 30 September 2019, we only evaluate ERA5-driven simulations during the period from 1 January 2018 to 30 June 2019. The first 4 years of the simulation data are considered the spinup stage of the model. Comparison of daily mean SST with OSTIA analysis and moored buoys observations is presented, while the daily mean SSH is compared with tide gauge observations. Moored observation buoys in the eastern tropical Indian Ocean established as part of the Research Moored Array for African-Asian-Australian Monsoon Analysis (RAMA, McPhaden et al., 2009) at the locations $5^{\circ} \mathrm{S}, 95^{\circ} \mathrm{E}\left(\mathrm{M}_{1}\right)$ and $8^{\circ} \mathrm{S}, 95^{\circ} \mathrm{E}\left(\mathrm{M}_{2}\right)$ are used for the evaluation. Fast-delivery (FD) data from UHSLC for 20 tide gauge stations are employed for the SSH comparison.

\subsubsection{Sea surface temperature}

Comparison of model-simulated daily mean SST with OSTIA analysis is shown in Fig. 4. Spatial distribution of model SST bias (Fig. 4a), root-mean-square difference (RMSD) (Fig. 4b), correlation coefficient (Fig. 4c) and the spatial average of SST difference over the analysis domain (Fig. 4d) are given. Model performance in simulating SST over the sub-regions is given in Table 2. SST Bias, RMSD, and correlation coefficient statistics computed using modelled SST and OSTIA are shown in Table 2. The SST bias is within $\pm 0.2^{\circ} \mathrm{C}$ for about $76 \%$ of the analysis domain and within $\pm 0.5^{\circ} \mathrm{C}$ for about $98 \%$ of the analysis domain. The largest SST cold bias is seen in the Andaman Sea region. Meanwhile, most of the South China Sea (SCS), equatorial western Pacific Ocean, and the Australian coast of the Timor Sea show a positive SST bias. Negative SST bias of about $-0.25^{\circ} \mathrm{C}$ is observed in the ASMS region, while positive bias over $0.25^{\circ} \mathrm{C}$ is confined to the SSCS and GoT sub-regions. Rather than appearing as a basin-wide feature, higher positive biases appear as small circular patches in the northern SCS region that represent the likely existence of cyclonic eddies over this region. 
(a) Model SST Bias

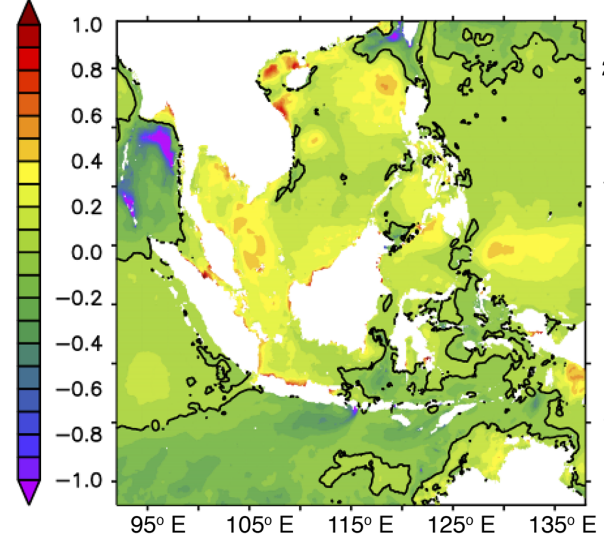

(c) Correlation

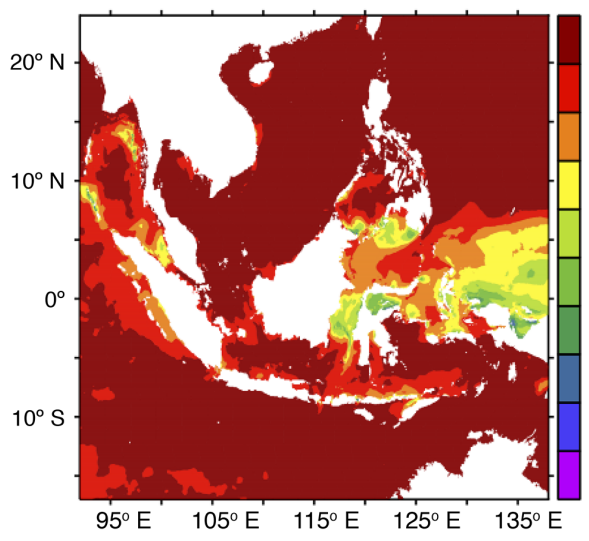

(b) SST RMSD

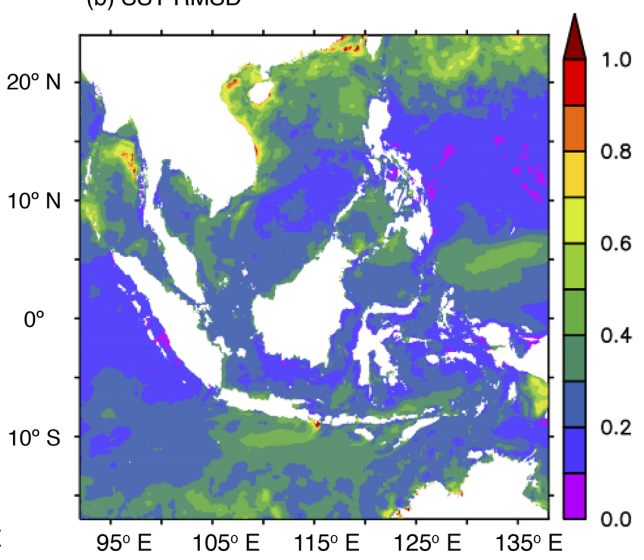

(d) Average SST Difference

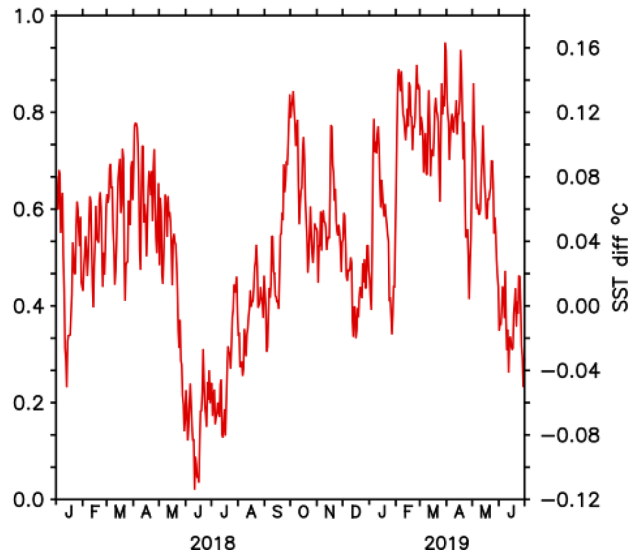

Figure 4. Spatial distribution of daily averaged (a) SST bias $\left({ }^{\circ} \mathrm{C}\right)$, (b) RMSD $\left({ }^{\circ} \mathrm{C}\right)$, and (c) correlation coefficient between the MCO hindcast and OSTIA analysis. (d) Spatial average of SST difference between the model and OSTIA over the analysis domain $\left({ }^{\circ} \mathrm{C}\right)$.

The RMSD between the model and OSTIA is less than $0.5^{\circ} \mathrm{C}$ for about $97 \%$ of the analysis domain (Fig. 4b). Small patches of higher RMSD $\left(>0.7^{\circ} \mathrm{C}\right)$ are mostly seen along the coastal regions. The RMSD minimum $\left(0.25^{\circ} \mathrm{C}\right)$ and maximum $\left(0.53^{\circ} \mathrm{C}\right)$ are observed over the BS and ASMS sub-regions, respectively (Table 2). Correlation between the model SST hindcast and OSTIA is above $99.9 \%$ confidence level over the analysis domain (Fig. 4c). Over $88 \%$ of the domain displays a correlation higher than 0.8. Relatively low correlation is seen over the middle of the Malacca Strait, Makassar Strait, and equatorial Pacific Ocean regions. In sub-region spatial average, the lowest (0.8) and highest (0.96) correlations are seen over the SuCeS and RSCS regions, respectively (Table 2). Time series of the spatially averaged SST difference between the model and OSTIA is shown in Fig. 4d. Consistent with our earlier analyses, relatively low SST difference depicts a good agreement between the MCO SST hindcast and OSTIA analysis. Further analysis of SST in different sub-regions revealed that relatively higher SST over the GoT, SSCS and SuCeS regions contribute to the positive SST differences during February-April in 2018 and
2019 and September-October in 2018 (figures not shown). Meanwhile, SST simulation over those sub-regions shows improvement during June-July 2018. Higher negative SST bias over the ASMS region mainly contributes to the negative SST difference during the same period. Overall, the mean SST bias, RMSD, and mean correlation over the analysis domain are $0.07^{\circ} \mathrm{C}, 0.34^{\circ} \mathrm{C}$, and 0.90 , respectively.

The time series of daily mean SST from the RAMA moored observation buoys located in the southeastern tropical Indian Ocean at $5^{\circ} \mathrm{S}, 95^{\circ} \mathrm{E}\left(\mathrm{M}_{1}\right)$ and $8^{\circ} \mathrm{S}, 95^{\circ} \mathrm{E}\left(\mathrm{M}_{2}\right)$ is shown in Fig. 5. Model SST is bilinearly interpolated to the buoy locations. Temperature observations at $1 \mathrm{~m}$ depth are taken as SST from the moored buoys, while temperature averaged over the upper $1 \mathrm{~m}$ is indicated as the model SST at these locations. In general, a good agreement is found between the model and observations at both mooring locations. Both the seasonal and intra-seasonal SST variability are reasonably well reproduced by the model. SST bias, RMSD, and correlation between the model and observation are $0.17^{\circ} \mathrm{C}$, $0.29^{\circ} \mathrm{C}$, and 0.94 , respectively, for $\mathrm{M}_{1}$ and $0.12^{\circ} \mathrm{C}, 0.41^{\circ} \mathrm{C}$, and 0.92 , respectively, for $\mathrm{M}_{2}$. The standard deviation (SD) 
Table 2. Summary of SST bias, RMSD, and correlation coefficient statistics between the model hindcast and OSTIA for the period 1 January 2018 to 30 June 2019. Daily mean SST from the model and OSTIA is used for the analysis.

\begin{tabular}{llrrr}
\hline No. & Region & $\begin{array}{r}\text { Bias } \\
\left({ }^{\circ} \mathrm{C}\right)\end{array}$ & $\begin{array}{r}\text { RMSD } \\
\left({ }^{\circ} \mathrm{C}\right)\end{array}$ & $\begin{array}{r}\text { Correlation } \\
\text { Coefficient }\end{array}$ \\
\hline 1 & Andaman Sea-Malacca Strait & -0.25 & 0.53 & 0.84 \\
2 & Southern SCS & 0.29 & 0.30 & 0.95 \\
3 & Gulf of Thailand & 0.26 & 0.30 & 0.94 \\
4 & Rest of SCS & 0.16 & 0.39 & 0.96 \\
5 & Tropical western Pacific Ocean & 0.07 & 0.29 & 0.88 \\
6 & Sulu-Celebes seas & 0.12 & 0.31 & 0.80 \\
7 & Banda Sea & 0.00 & 0.25 & 0.84 \\
8 & Java Sea & 0.09 & 0.30 & 0.89 \\
9 & Timor-Arafura seas & 0.01 & 0.34 & 0.95 \\
10 & Tropical eastern Indian Ocean & -0.05 & 0.30 & 0.92 \\
Mean value & 0.07 & 0.34 & 0.90 \\
\hline
\end{tabular}

(a) SST $M_{1}\left(5^{\circ} S, 95^{\circ} \mathrm{E}\right)$
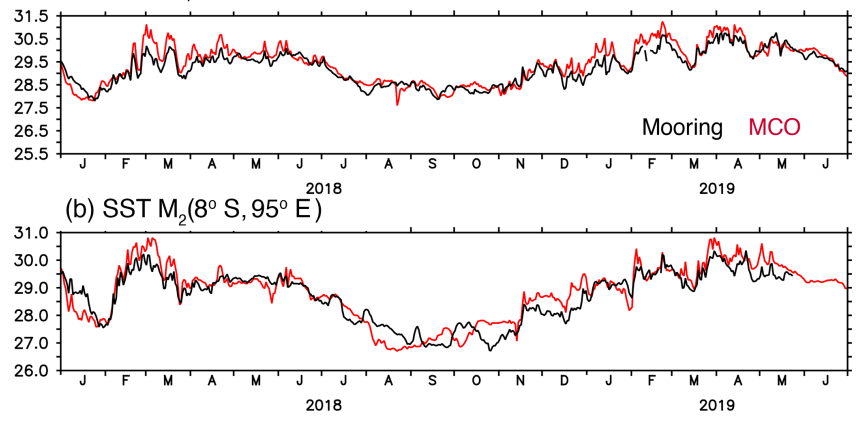

Figure 5. Comparison of daily averaged SST from MCO hindcast and RAMA moored buoys at (a) $\mathrm{M}_{1}$ and (b) $\mathrm{M}_{2}$ during the period 1 January 2018 to 30 June 2019.

of SST at $\mathrm{M}_{1}$ and $\mathrm{M}_{2}$ are $0.94{ }^{\circ} \mathrm{C}$ and $0.99^{\circ} \mathrm{C}$, respectively, and the RMSD is smaller than the SD at both locations.

\subsubsection{Sea surface height}

Daily mean SSH observation from 20 tide-gauge stations distributed across the domain and MCO simulated SSH interpolated to the location of these observations have been used for the hindcast evaluation. SSH bias, RMSD and correlation coefficient statistics between model and SSH observations are given in Table 3 . Highest SSH bias $(0.12 \mathrm{~m})$ and RMSD $(0.15 \mathrm{~m})$ are seen at the Malakal, Palau, tide gauge station. The SSH bias is within $\pm 0.05 \mathrm{~m}$ for 17 of the total 20 stations analysed. The model accuracy is higher than $0.10 \mathrm{~m}$ for 18 stations, while 14 of the total 20 stations have an accuracy greater than $0.05 \mathrm{~m}$. The $\mathrm{SSH}$ correlation between the model and observations is above $99.9 \%$ confidence level for all tide gauge stations employed in the analysis. The correlation is above 0.80 for 16 tide gauge stations. Lowest correlation of 0.60 is observed at the Malakal tide gauge station. Mean SSH bias, RMSD, and mean correlation between the model and observation are $0.01 \mathrm{~m}, 0.06 \mathrm{~m}$, and 0.87 , respectively.

Time series of daily mean SSH from model and observations for randomly selected stations are plotted in Fig. 6. The stations Sibolga and Prigi are located in the eastern tropical Indian Ocean, and Currimao Ilocos Norte and Vung Tau are located in the SCS. Generally, the model-simulated SSH follows the observation and shows good agreement with it. A few sharp peaks in the tide gauge observation are found to be absent in the model simulation (e.g. Fig. 6c). Most of the tide gauge stations are located adjacent to the coast, and our current model resolution is not enough to resolve the coastline at very fine scales. Since the model SSH is interpolated to the tide gauge location, local-scale SSH variations may not be captured in the model simulation. This may be one possible reason for the discrepancy between the model and observations.

Comparison of model-simulated SST and SSH fields shows good agreement with observation and analysis data. The RMSD and bias statistics of SST and SSH relative to the observation are within the acceptable error limits of ocean hindcast simulations (e.g. Yang et al., 2016). Statistically significant correlation with observation suggests that both the spatial and temporal patterns of variability are reasonably well reproduced by the model.

\subsection{Ocean forecasts}

Results from the analysis of $\mathrm{MCO}_{\mathrm{ao}}$ forecast simulations for October 2020 are presented here. Since the system delivers a $6 \mathrm{~d}$ forecast, the analysis period extends from 1 October to 5 November 2020. Daily files are produced at different forecast lead times, $T+0$ to $T+24$ (fcst_day 1 ), $T+24$ to $T+48$ (fcst_day2), $T+48$ to $T+72$ (fcst_day3), $T+72$ to $T+96$ (fcst_day4), $T+96$ to $T+120$ (fcst_day5), and $T+120$ to $T+144$ (fcst_day6) for the following analyses. Comparisons of coupled ocean forecasts for different forecast lead times 
Table 3. Summary of SSH bias, RMSD, and correlation coefficient statistics between MCO hindcast and tide gauge stations for the period 1 January 2018 to 30 June 2019. Daily mean SSH from model and tide gauge is used for the analysis.

\begin{tabular}{lllrrr}
\hline No & $\begin{array}{l}\text { Station name and } \\
\text { country }\end{array}$ & $\begin{array}{l}\text { Latitude, } \\
\text { longitude }\end{array}$ & $\begin{array}{r}\text { Bias } \\
(\mathrm{m})\end{array}$ & $\begin{array}{r}\text { RMSD } \\
(\mathrm{m})\end{array}$ & $\begin{array}{r}\text { Correlation } \\
\text { coefficient }\end{array}$ \\
\hline 1 & Sabang, Indonesia & $5.888^{\circ} \mathrm{N}, 95.317^{\circ} \mathrm{E}$ & 0.00 & 0.04 & 0.85 \\
2 & Sibolga, Indonesia & $1.75^{\circ} \mathrm{N}, 98.767^{\circ} \mathrm{E}$ & 0.01 & 0.03 & 0.90 \\
3 & Padang, Indonesia & $1.0^{\circ} \mathrm{S}, 100.367^{\circ} \mathrm{E}$ & -0.05 & 0.06 & 0.89 \\
4 & Cilicap, Indonesia & $7.752^{\circ} \mathrm{S}, 109.017^{\circ} \mathrm{E}$ & 0.00 & 0.04 & 0.93 \\
5 & Prigi, Indonesia & $8.28^{\circ} \mathrm{S}, 111.73^{\circ} \mathrm{E}$ & 0.00 & 0.05 & 0.96 \\
6 & Benoa, Indonesia & $8.745^{\circ} \mathrm{S}, 115.21^{\circ} \mathrm{E}$ & 0.00 & 0.04 & 0.94 \\
7 & Saumlaki, Indonesia & $7.982^{\circ} \mathrm{S}, 131.29^{\circ} \mathrm{E}$ & 0.02 & 0.05 & 0.81 \\
8 & Bitung, Indonesia & $1.44^{\circ} \mathrm{N}, 125.193^{\circ} \mathrm{E}$ & 0.06 & 0.07 & 0.73 \\
9 & Malakal, Palau & $7.33^{\circ} \mathrm{N}, 134.463^{\circ} \mathrm{E}$ & 0.12 & 0.15 & 0.60 \\
10 & Davao Gulf, Philippines & $7.122^{\circ} \mathrm{N}, 125.663^{\circ} \mathrm{E}$ & 0.00 & 0.03 & 0.88 \\
11 & Subic Bay, Philippines & $14.765^{\circ} \mathrm{N}, 120.252^{\circ} \mathrm{E}$ & 0.04 & 0.05 & 0.94 \\
12 & Manila, Philippines & $14.585^{\circ} \mathrm{N}, 120.968^{\circ} \mathrm{E}$ & -0.01 & 0.04 & 0.95 \\
13 & Legaspi, Philippines & $13.15^{\circ} \mathrm{N}, 123.75^{\circ} \mathrm{E}$ & 0.00 & 0.03 & 0.83 \\
14 & Currimao Ilocos Norte, Philippines & $17.988^{\circ} \mathrm{N}, 120.488^{\circ} \mathrm{E}$ & 0.00 & 0.05 & 0.96 \\
15 & Hong Kong, China & $22.3^{\circ} \mathrm{N}, 114.2^{\circ} \mathrm{E}$ & -0.02 & 0.09 & 0.75 \\
16 & Qui Nhon, Viet Nam & $13.775^{\circ} \mathrm{N}, 109.255^{\circ} \mathrm{E}$ & 0.01 & 0.05 & 0.90 \\
17 & Vung Tau, Viet Nam & $10.34^{\circ} \mathrm{N}, 107.072^{\circ} \mathrm{E}$ & 0.01 & 0.07 & 0.90 \\
18 & Ko Lak, Thailand & $11.795^{\circ} \mathrm{N}, 99.817^{\circ} \mathrm{E}$ & -0.01 & 0.06 & 0.95 \\
19 & Ko Taphao Noi, Thailand & $7.832^{\circ} \mathrm{N}, 98.425^{\circ} \mathrm{E}$ & 0.00 & 0.04 & 0.91 \\
20 & Pulau Langkawi, Malaysia & $6.432^{\circ} \mathrm{N}, 99.765^{\circ} \mathrm{E}$ & -0.03 & 0.14 & 0.72 \\
Mean values & & 0.01 & 0.06 & 0.87 \\
\hline
\end{tabular}

with OSTIA SST and in situ observations have been performed, such as temperature from RAMA moored buoys, TSG, and XBT profiles; temperature and salinity from conductivity temperature depth (CTD) profiles; and SSH from tide gauges.

\subsubsection{Sea surface temperature}

Time series of daily mean SST averaged over the sub-regions from OSTIA analysis and different forecast lead times are plotted in Fig. 7. Statistics of SST bias, RMSD, and correlation coefficient between the model and OSTIA for the October forecast run are listed in Table 4. The forecasted SST over most of the sub-regions is within the error standard deviation of the OSTIA analysis, which is indicated by shading in Fig. 7. Excluding the ASMS, all other sub-regions exhibit a warm SST bias, with the largest values over the SSCS and GoT. The RMSD is less than $0.5^{\circ} \mathrm{C}$ over most of the sub-regions during the analysis period. Over the ASMS sub-region, both the cold bias and RMSD increase with the forecast lead time, and it shows the highest RMSD $\left(0.49^{\circ} \mathrm{C}\right)$ on fsct_day6. The largest SST RMSD $\left(0.56^{\circ} \mathrm{C}\right)$ and bias $\left(0.49^{\circ} \mathrm{C}\right)$ over all sub-regions is observed over the GoT with a $1 \mathrm{~d}$ forecast lead time. Generally, the forecasted SST tends to be cooler, with an increase in forecast lead time denoting a lower warm bias and RMSD relative to fcst_day1. Interestingly, inconsistent with the improvements in SST bias and RMSD, the correlation between forecasted and OSTIA time series considerably decreases with higher forecast lead times (Table 4).

SST correlation is above the $95 \%$ confidence level $(r>0.365)$ over the entire analysis domain during fcst_day1. In general, SST correlation is higher than $99 \%$ confidence level $(r>0.46)$ over $60 \%$ of the sub-regions during higher forecast lead times as well. The sub-regions including ASMS, GoT, TWPO, and SuCeS are noted by lower correlation significance level with an increase in forecast lead time. Overall, the SST correlation over the analysis domain is above the $99 \%$ confidence level across all forecast lead times, while bias and RMSD are less than 0.19 and $0.35^{\circ} \mathrm{C}$, respectively.

Figure 8 shows the time series of hourly averaged SST at $\mathrm{M}_{1}$ (Fig. 8a) and $\mathrm{M}_{2}$ (Fig. 8b) mooring locations from observation and model forecasts. It should be noted that the observation at $\mathrm{M}_{2}$ is available for a relatively short period from 21 October to 5 November 2020. Statistics of the SST bias, RMSD, and correlation coefficient between the model forecast and the observations are listed in Table 5. The diurnal variability of SST at both locations is reasonably well reproduced by the model in all forecast lead times. However, the model forecasts have overestimated the SST diurnal variations from 23 October 2019. SST cooling during late October-early August 2020 at the location $\mathrm{M}_{1}$ is underestimated in the model forecast. SST bias and RMSD at $\mathrm{M}_{1}$ are less than 0.07 and $0.20^{\circ} \mathrm{C}$, respectively, and remain fairly constant across all forecast lead times. Despite this, the cor- 
(a) Sibolga, Indonesia

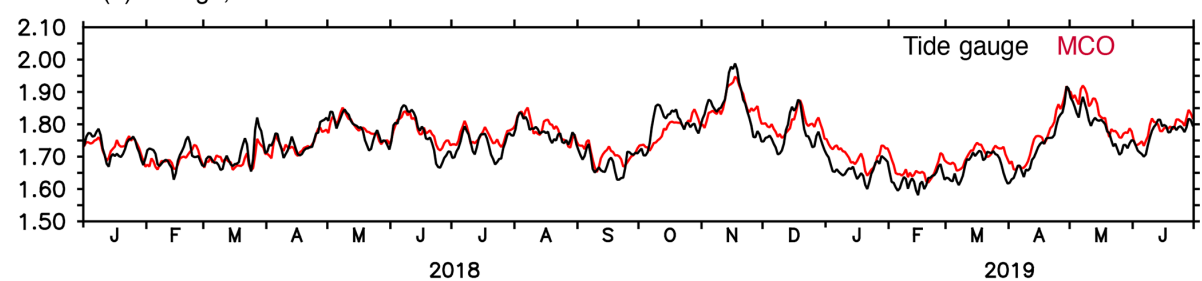

(b) Prigi, Indonesia

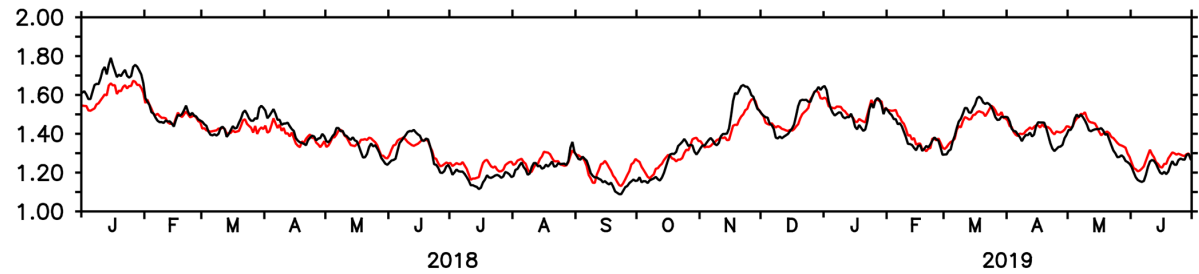

(c) Currimao llocos Norte, Philippines

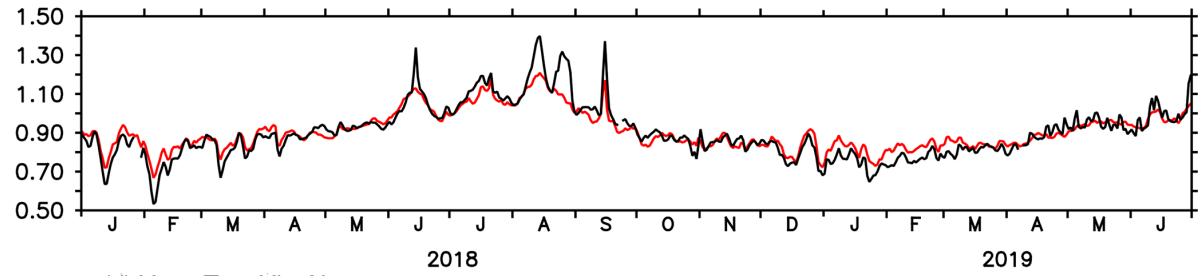

(d) Vung Tau, Viet Nam

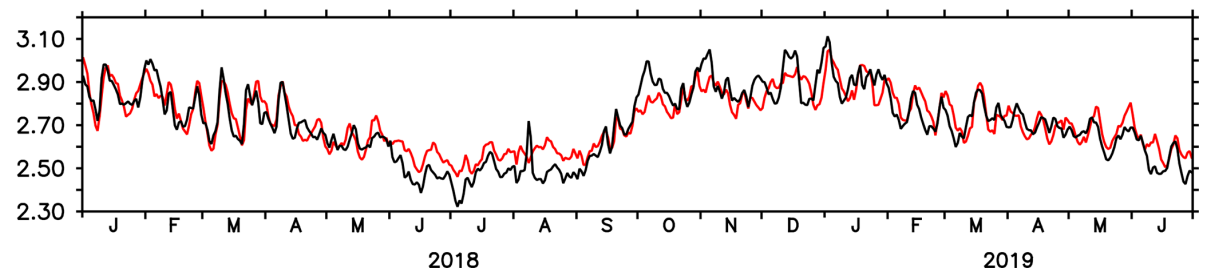

Figure 6. Time series of daily mean SSH (in metres) from tide gauge observations (black line) and MCO hindcasts (red line) at randomly selected stations, (a) Sibolga $\left(1.75^{\circ} \mathrm{N}, 98.76^{\circ} \mathrm{E}\right)$, (b) Prigi $\left(8.28^{\circ} \mathrm{S}, 111.73^{\circ} \mathrm{N}\right)$, (c) Currimao Ilocos Norte $\left(17.988^{\circ} \mathrm{N}, 120.488^{\circ} \mathrm{E}\right)$, and (d) Vung Tau $\left(10.34^{\circ} \mathrm{N}, 107.072^{\circ} \mathrm{E}\right)$, from 1 January 2018 to 30 June 2019.

relation between model forecasts and observations depicts a considerable decrease at higher forecast lead times. A cold SST bias of about -0.14 to $-0.17^{\circ} \mathrm{C}$ is noted at location $\mathrm{M}_{2}$. The RMSD at $\mathbf{M}_{2}$ is relatively low, with a maximum of $0.18^{\circ} \mathrm{C}$ across all forecast lead times while compared to $\mathrm{M}_{1}$. The SST correlation at $\mathrm{M}_{2}$ is above the $95 \%$ confidence level $(r>0.61, \mathrm{df} \geq 9)$ during all forecast lead times.

\subsubsection{Temperature and salinity}

Temperature and salinity data available from the CORIOLIS data portal are employed for the $\mathrm{MCO}_{\mathrm{ao}}$ forecast evaluation of subsurface fields. Argo and XBT profiles, moored buoys, and TSG observations are used for the analysis. We only consider mooring and TSG observations with a minimum of $10 \mathrm{~d}$ for the analysis. TSG observation selected for the analysis is located in the Timor and Arafura seas, and the track has a direction of motion towards the west (Fig. 3). Continuous observations available at $6.4 \mathrm{~m}$ depth are compared with the model forecasts. Currently, the fore- cast system produces only daily averaged subsurface variables. Hence, the instantaneous TSG temperature observations at 12:00 UTC are compared with the daily averaged model temperature. Time series of TSG temperature observations and model forecasts for different forecast lead times are shown in Fig. 8c. Though the model temperature shows a negative bias, daily temperature variation is reasonably well predicted by the model. This is supported by the high correlation, above the $99.9 \%$ confidence level, between the model forecast and observation (Table 5, item 3). The largest temperature bias and RMSD are $-0.47^{\circ} \mathrm{C}$ and $0.68^{\circ} \mathrm{C}$, respectively, and significant variations in bias, RMSD, and correlation statistics are not noticeable.

The moored buoy observations provide a unique opportunity to assess the model simulations both in the surface and subsurface of the ocean. Since the variables of interest in the present study are temperature and salinity, we have tried to compare the model forecast of temperature and salinity with buoy observation available at the locations $\mathrm{M}_{1}$ and 
Table 4. Summary of SST bias and RMSD (a) and correlation coefficient (b) statistics between coupled ocean forecasts and OSTIA over the sub-regions shown in Fig. 3 from 1 to 31 October 2019. Daily mean SST from model and OSTIA is used for the analysis.

\begin{tabular}{|c|c|c|c|c|c|c|c|c|c|c|c|c|c|}
\hline \multirow[t]{3}{*}{ (a) $\mathrm{N}$} & & \multicolumn{6}{|c|}{$\operatorname{Bias}\left({ }^{\circ} \mathrm{C}\right)$} & \multicolumn{6}{|c|}{$\operatorname{RMSD}\left({ }^{\circ} \mathrm{C}\right)$} \\
\hline & & \multicolumn{6}{|c|}{ Forecast lead time (d) } & \multicolumn{6}{|c|}{ Forecast lead time (d) } \\
\hline & & 1 & 2 & 3 & 4 & 5 & 6 & 1 & 2 & 3 & 4 & 5 & 6 \\
\hline 1 & Andaman Sea-Malacca Strait & -0.01 & -0.11 & -0.13 & -0.14 & -0.15 & -0.17 & 0.40 & 0.41 & 0.41 & 0.43 & 0.46 & 0.49 \\
\hline 2 & Southern SCS & 0.43 & 0.32 & 0.27 & 0.20 & 0.20 & 0.20 & 0.50 & 0.41 & 0.36 & 0.30 & 0.30 & 0.30 \\
\hline 3 & Gulf of Thailand & 0.49 & 0.38 & 0.29 & 0.28 & 0.25 & 0.23 & 0.56 & 0.47 & 0.37 & 0.38 & 0.34 & 0.33 \\
\hline 4 & Rest of SCS & 0.16 & 0.10 & 0.08 & 0.07 & 0.05 & 0.05 & 0.30 & 0.24 & 0.22 & 0.21 & 0.20 & 0.21 \\
\hline 5 & Tropical western Pacific Ocean & 0.11 & 0.11 & 0.10 & 0.09 & 0.08 & 0.07 & 0.21 & 0.22 & 0.21 & 0.20 & 0.20 & 0.21 \\
\hline 6 & Sulu-Celebes seas & 0.21 & 0.14 & 0.13 & 0.11 & 0.10 & 0.10 & 0.33 & 0.27 & 0.27 & 0.26 & 0.26 & 0.26 \\
\hline 7 & Banda Sea & 0.13 & 0.10 & 0.10 & 0.10 & 0.10 & 0.11 & 0.21 & 0.19 & 0.19 & 0.19 & 0.21 & 0.23 \\
\hline 8 & Java Sea & 0.15 & 0.10 & 0.09 & 0.07 & 0.06 & 0.05 & 0.25 & 0.21 & 0.21 & 0.20 & 0.19 & 0.19 \\
\hline 9 & Timor-Arafura seas & 0.18 & 0.17 & 0.17 & 0.17 & 0.17 & 0.17 & 0.34 & 0.34 & 0.34 & 0.34 & 0.35 & 0.37 \\
\hline 10 & Tropical eastern Indian Ocean & 0.02 & 0.02 & 0.02 & 0.02 & 0.01 & 0.01 & 0.25 & 0.23 & 0.22 & 0.22 & 0.22 & 0.22 \\
\hline \multirow{2}{*}{\multicolumn{2}{|c|}{ Mean values }} & 0.19 & 0.13 & 0.11 & 0.10 & 0.09 & 0.08 & 0.35 & 0.31 & 0.29 & 0.28 & 0.29 & 0.29 \\
\hline & & \multicolumn{6}{|c|}{0.12} & \multicolumn{6}{|c|}{0.30} \\
\hline \multirow{3}{*}{\multicolumn{2}{|c|}{ (b) No. }} & \multicolumn{6}{|c|}{ Correlation coefficient } & & & & & & \\
\hline & & \multicolumn{6}{|c|}{ Forecast lead time (d) } & & & & & & \\
\hline & & 1 & 2 & 3 & 4 & 5 & 6 & & & & & & \\
\hline 1 & Andaman Sea-Malacca Strait & 0.37 & 0.37 & 0.31 & 0.23 & 0.16 & 0.15 & & & & & & \\
\hline 2 & Southern SCS & 0.63 & 0.50 & 0.52 & 0.53 & 0.51 & 0.49 & & & & & & \\
\hline 3 & Gulf of Thailand & 0.48 & 0.41 & 0.38 & 0.33 & 0.30 & 0.37 & & & & & & \\
\hline 4 & Rest of SCS & 0.65 & 0.63 & 0.62 & 0.63 & 0.62 & 0.61 & & & & & & \\
\hline 5 & Tropical western Pacific Ocean & 0.58 & 0.49 & 0.45 & 0.39 & 0.34 & 0.30 & & & & & & \\
\hline 6 & Sulu-Celebes seas & 0.40 & 0.35 & 0.30 & 0.27 & 0.25 & 0.24 & & & & & & \\
\hline 7 & Banda Sea & 0.84 & 0.82 & 0.83 & 0.80 & 0.77 & 0.72 & & & & & & \\
\hline 8 & Java Sea & 0.88 & 0.88 & 0.87 & 0.87 & 0.86 & 0.85 & & & & & & \\
\hline 9 & Timor-Arafura seas & 0.83 & 0.84 & 0.84 & 0.82 & 0.79 & 0.76 & & & & & & \\
\hline 10 & Tropical eastern Indian Ocean & 0.53 & 0.54 & 0.53 & 0.52 & 0.50 & 0.47 & & & & & & \\
\hline \multirow{2}{*}{\multicolumn{2}{|c|}{ Mean value }} & 0.62 & 0.58 & 0.57 & 0.54 & 0.51 & 0.50 & & & & & & \\
\hline & & \multicolumn{6}{|c|}{0.55} & & & & & & \\
\hline
\end{tabular}

Table 5. Items (1) and (2) are a summary of SST bias and RMSD (a) and correlation coefficient (b) statistics between coupled ocean forecasts and observations at the mooring locations $\mathrm{M}_{1}\left(5^{\circ} \mathrm{S}, 95^{\circ} \mathrm{E}\right)$ and $\mathrm{M}_{2}\left(8^{\circ} \mathrm{S}, 95^{\circ} \mathrm{E}\right)$ during October 2019 . Hourly averaged temperature from the model and observations is used for the analysis. Item (3) is the same as items (1) and (2) but for temperatures at $6.4 \mathrm{~m}$ depth along the track shown in Fig. 3. Daily averaged temperature from model and instantaneous temperature at 12:00 UTC from observation is used for the analysis. Item (4) is the same as items (1) and (2) but for temperatures within 0 to $600 \mathrm{~m}$ depth at the mooring location $\mathrm{M}_{1}$. Daily averaged temperature model and observations used in the analysis.

\begin{tabular}{|c|c|c|c|c|c|c|c|c|c|c|c|c|c|}
\hline \multirow[t]{3}{*}{ (a) No. } & & \multicolumn{6}{|c|}{$\operatorname{Bias}\left({ }^{\circ} \mathrm{C}\right)$} & \multicolumn{6}{|c|}{$\operatorname{RMSD}\left({ }^{\circ} \mathrm{C}\right)$} \\
\hline & & \multicolumn{6}{|c|}{ Forecast lead time (d) } & \multicolumn{6}{|c|}{ Forecast lead time (d) } \\
\hline & & 1 & 2 & 3 & 4 & 5 & 6 & 1 & 2 & 3 & 4 & 5 & 6 \\
\hline (1) & $\mathrm{SST} \mathrm{M}_{1}\left(5^{\circ} \mathrm{S}, 95^{\circ} \mathrm{E}\right)$ & 0.07 & 0.06 & 0.06 & 0.06 & 0.06 & 0.06 & 0.19 & 0.19 & 0.19 & 0.18 & 0.20 & 0.20 \\
\hline (2) & $\mathrm{SST} \mathrm{M}_{2}\left(8^{\circ} \mathrm{S}, 95^{\circ} \mathrm{E}\right)$ & -0.14 & -0.17 & -0.17 & -0.15 & -0.15 & -0.16 & 0.15 & 0.18 & 0.18 & 0.17 & 0.17 & 0.18 \\
\hline (3) & Temp (TSG, $z=6.4 \mathrm{~m})$ & -0.47 & -0.43 & -0.43 & -0.43 & -0.41 & -0.46 & -0.65 & 0.65 & 0.66 & 0.68 & 0.64 & 0.64 \\
\hline (4) & Temp $\mathrm{M}_{1}\left(z=0-600 \mathrm{~m}, 5^{\circ} \mathrm{S}, 95^{\circ} \mathrm{E}\right)$ & 1.87 & 1.87 & 1.88 & 1.91 & 1.91 & 1.95 & 2.83 & 2.82 & 2.83 & 2.88 & 2.89 & 2.96 \\
\hline \multirow[t]{3}{*}{ (b) No. } & & \multicolumn{6}{|c|}{ Correlation coefficient } & & & & & & \\
\hline & & \multicolumn{6}{|c|}{ Forecast lead time (d) } & & & & & & \\
\hline & & 1 & 2 & 3 & 4 & 5 & 6 & & & & & & \\
\hline (1) & $\mathrm{SST} \mathrm{M}_{1}\left(5^{\circ} \mathrm{S}, 95^{\circ} \mathrm{E}\right)$ & 0.77 & 0.74 & 0.61 & 0.54 & 0.34 & 0.24 & & & & & & \\
\hline (2) & $\mathrm{SST} \mathrm{M}_{2}\left(8^{\circ} \mathrm{S}, 95^{\circ} \mathrm{E}\right)$ & 0.94 & 0.91 & 0.83 & 0.79 & 0.78 & 0.68 & & & & & & \\
\hline (3) & Temp (TSG, $z=6.4 \mathrm{~m})$ & 0.87 & 0.86 & 0.85 & 0.83 & 0.84 & 0.86 & & & & & & \\
\hline (4) & Temp $\mathrm{M}_{1}\left(z=0-600 \mathrm{~m}, 5^{\circ} \mathrm{S}, 95^{\circ} \mathrm{E}\right)$ & 0.60 & 0.61 & 0.58 & 0.55 & 0.52 & 0.56 & & & & & & \\
\hline
\end{tabular}


(a) ASMS

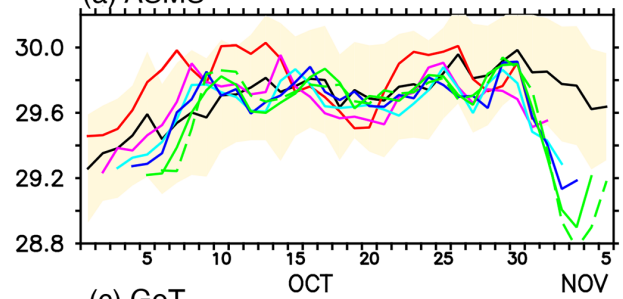

(c) GoT
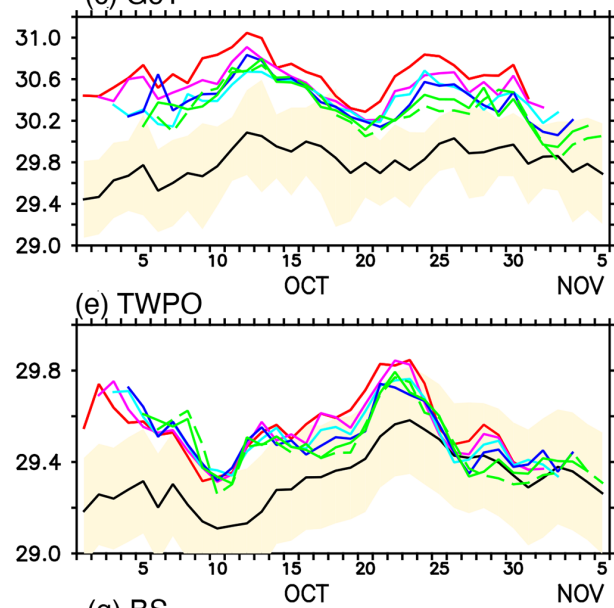

(g) BS
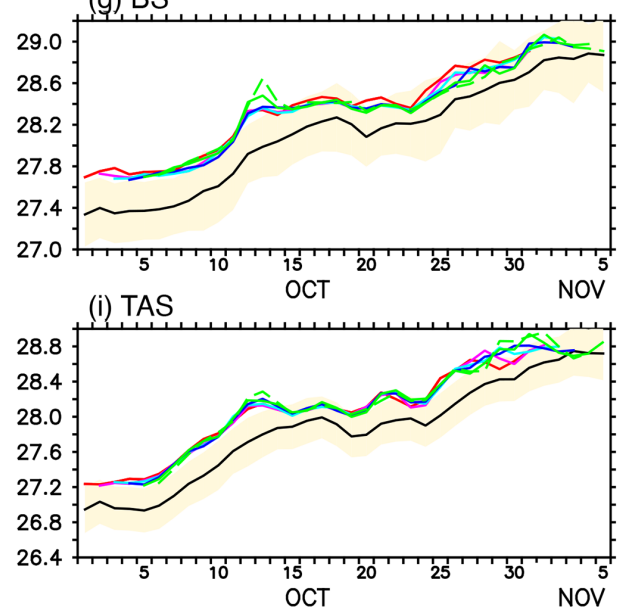

(b) SSCS

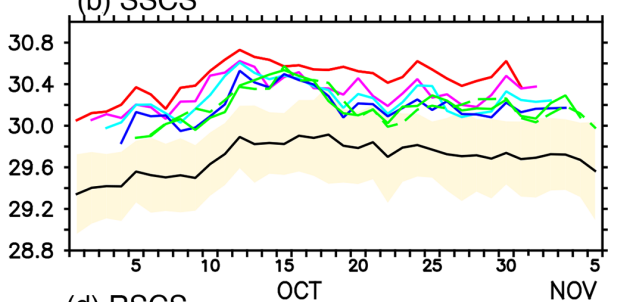

(d) RSCS
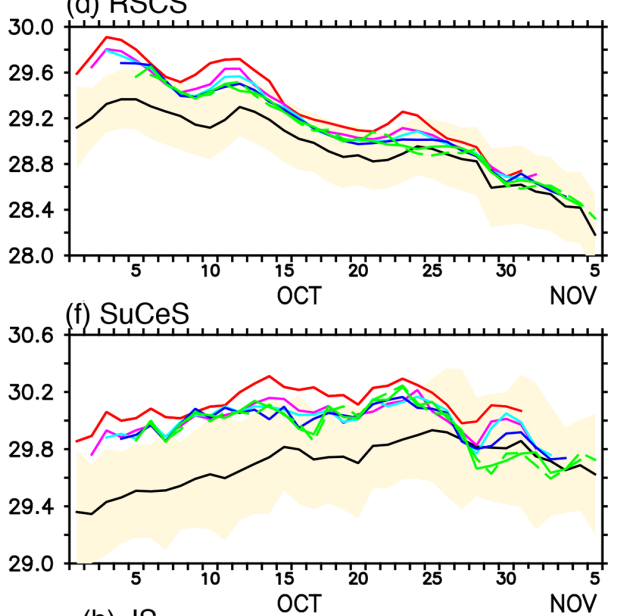

(h) JS
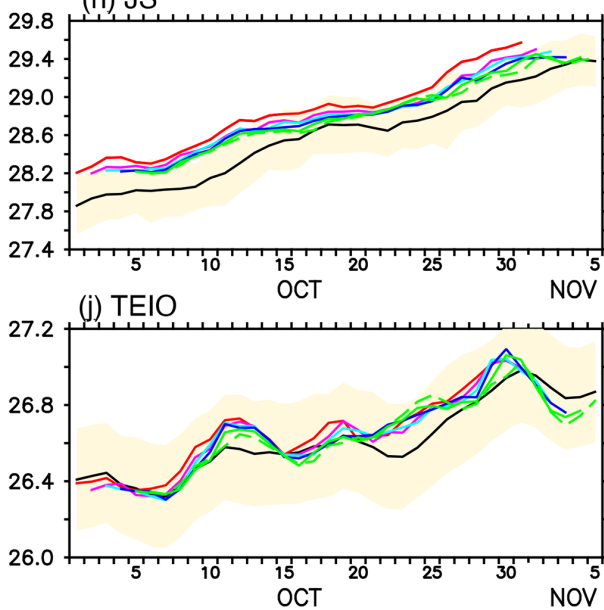

Figure 7. Time series of daily mean SST from model forecast and OSTIA averaged over the sub-regions: OSTIA (black line), fcst_day1 (red line), fcst_day2 (purple line), fcst_day3 (light blue line), fcst_day4 (blue line), fcst_day5 (green line), and fcst_day6 (dashed green line). Shading represents the estimated error standard deviation of analysed SST in OSTIA. (a) ASMS stands for Andaman Sea-Malacca Strait, (b) SSCS stands for southern SCS, (c) GoT stands for Gulf of Thailand, (d) RSCS represents the rest of the SCS, (e) TWPO stands for tropical western Pacific Ocean, (f) SuCeS stands for the Sulu-Celebes seas, (g) BS stands for the Banda Sea, (h) JS stands for the Java Sea, (i) TAS stands for the Timor-Arafura seas, (j) TEIO stands for tropical eastern Indian Ocean. The $y$ axes are differ between the plots.

$\mathrm{M}_{2}$. However, due to data gaps and shorter time series, salinity observation from both moorings and temperature from $\mathrm{M}_{2}$ mooring are not included in the analysis. Depth-time plots of temperature from the model for forecast lead times $1 \mathrm{~d}$ (fcst_day1), $3 \mathrm{~d}$ (fcst_day3), and $5 \mathrm{~d}$ (fcst_day5) and the moored observation $\left(\mathrm{M}_{1}\right)$ are shown in Fig. 9. Statistics of temperature bias, RMSD, and correlation coefficient between the model forecast and observations are given in Table 5. The depth of the upper ocean isothermal and mixed layer and its shoaling in late October are well simulated by the model. A significant difference between the model forecast and observations is seen in the region below the mixed layer. The model simulation is unable to reproduce the sharp temperature stratification and cooling in the thermocline regions, while this feature is clearly evident in the observations. This leads to a relatively large discrepancy between the model and observation in the subsurface region roughly between 100 to $250 \mathrm{~m}$ depths. The usage of daily averaged temperature 
Table 6. Summary of temperature and salinity RMSD statistics between coupled ocean forecasts and in situ (Argo profile and XBT) observations from 1 October to 5 November 2019. Daily averaged temperature from the model and instantaneous temperature or salinity from observations are used for the analysis. Numbers in bold indicate the number of profiles analysed for each variable and lead forecast time.

\begin{tabular}{lrrrrrrrr}
\hline & \multicolumn{8}{c}{ RMSD } \\
\cline { 2 - 7 } & 1 & 2 & 3 & 4 & 5 & 6 & \multirow{2}{*}{ All forecasts } \\
\cline { 2 - 7 } & 1.40 & 1.41 & 1.40 & 1.41 & 1.41 & 1.41 & 1.41 \\
\hline Temperature $\left({ }^{\circ} \mathrm{C}\right)$ & $\mathbf{2 5 5}$ & $\mathbf{2 5 1}$ & $\mathbf{2 5 0}$ & $\mathbf{2 4 6}$ & $\mathbf{2 4 5}$ & $\mathbf{2 4 5}$ & \\
$\mathbf{2 7 8}$ & 0.14 & 0.14 & 0.14 & 0.14 & 0.15 & 0.14 & 0.14 \\
\hline Salinity (psu) & $\mathbf{2 2 6}$ & $\mathbf{2 2 3}$ & $\mathbf{2 2 2}$ & $\mathbf{2 1 7}$ & $\mathbf{2 1 6}$ & $\mathbf{2 1 6}$ & \\
$\mathbf{2 4 4}$ & & & & & & & \\
\hline
\end{tabular}

Table 7. Summary of SSH RMSD and bias statistics between coupled ocean forecasts and tide gauge observations during October 2019. Hourly instantaneous SSH from the model and observations is used for the analysis.

\begin{tabular}{|c|c|c|c|c|c|c|c|c|c|c|c|c|c|c|}
\hline \multirow[t]{3}{*}{ No. } & \multirow[t]{3}{*}{$\begin{array}{l}\text { Station name \& } \\
\text { country }\end{array}$} & \multirow[t]{3}{*}{$\begin{array}{l}\text { Latitude, } \\
\text { longitude }\end{array}$} & \multicolumn{6}{|c|}{$\begin{array}{l}\text { RMSD } \\
(\mathrm{m})\end{array}$} & \multicolumn{6}{|c|}{$\begin{array}{l}\text { Bias } \\
(\mathrm{m})\end{array}$} \\
\hline & & & \multicolumn{6}{|c|}{ Forecast lead time (days) } & \multicolumn{6}{|c|}{ Forecast lead time (days) } \\
\hline & & & 1 & 2 & 3 & 4 & 5 & 6 & 1 & 2 & 3 & 4 & 5 & 6 \\
\hline 1 & Sabang, Indonesia & $5.888^{\circ} \mathrm{N}, 95.317^{\circ} \mathrm{E}$ & 0.06 & 0.06 & 0.06 & 0.06 & 0.06 & 0.07 & 0.01 & 0.01 & 0.01 & 0.01 & 0.02 & 0.02 \\
\hline 2 & Sibolga, Indonesia & $1.75^{\circ} \mathrm{N}, 98.767^{\circ} \mathrm{E}$ & 0.07 & 0.06 & 0.06 & 0.07 & 0.07 & 0.08 & 0.01 & 0.02 & 0.03 & 0.04 & 0.04 & 0.05 \\
\hline 3 & Padang, Indonesia & $1.0^{\circ} \mathrm{S}, 100.367^{\circ} \mathrm{E}$ & 0.05 & 0.05 & 0.05 & 0.05 & 0.05 & 0.05 & 0.00 & 0.00 & 0.00 & 0.00 & 0.00 & 0.00 \\
\hline 4 & Cilicap, Indonesia & $7.752^{\circ} \mathrm{S}, 109.017^{\circ} \mathrm{E}$ & 0.09 & 0.08 & 0.08 & 0.08 & 0.08 & 0.08 & 0.04 & 0.04 & 0.04 & 0.04 & 0.04 & 0.04 \\
\hline 5 & Prigi, Indonesia & $8.28^{\circ} \mathrm{S}, 111.73^{\circ} \mathrm{E}$ & 0.10 & 0.10 & 0.11 & 0.11 & 0.11 & 0.11 & 0.05 & 0.05 & 0.06 & 0.06 & 0.06 & 0.07 \\
\hline 6 & Benoa, Indonesia & $8.745^{\circ} \mathrm{S}, 115.21^{\circ} \mathrm{E}$ & 0.11 & 0.10 & 0.10 & 0.10 & 0.10 & 0.10 & -0.03 & -0.03 & -0.02 & -0.02 & -0.02 & -0.02 \\
\hline 7 & Saumlaki, Indonesia & $7.982^{\circ} \mathrm{S}, 131.29^{\circ} \mathrm{E}$ & 0.10 & 0.10 & 0.10 & 0.10 & 0.11 & 0.11 & 0.05 & 0.05 & 0.05 & 0.06 & 0.06 & 0.06 \\
\hline 8 & Bitung, Indonesia & $1.44^{\circ} \mathrm{N}, 125.193^{\circ} \mathrm{E}$ & 0.10 & 0.10 & 0.10 & 0.10 & 0.10 & 0.10 & 0.08 & 0.08 & 0.08 & 0.08 & 0.08 & 0.08 \\
\hline 9 & Malakal, Palau & $7.33^{\circ} \mathrm{N}, 134.463^{\circ} \mathrm{E}$ & 0.07 & 0.07 & 0.07 & 0.07 & 0.07 & 0.07 & 0.01 & 0.01 & 0.01 & 0.01 & 0.01 & 0.01 \\
\hline 10 & Davao Gulf, Philippines & $7.122^{\circ} \mathrm{N}, 125.663^{\circ} \mathrm{E}$ & 0.08 & 0.09 & 0.09 & 0.09 & 0.09 & 0.09 & -0.03 & -0.03 & -0.02 & -0.02 & -0.02 & -0.01 \\
\hline 11 & Subic Bay, Philippines & $14.765^{\circ} \mathrm{N}, 120.252^{\circ} \mathrm{E}$ & 0.04 & 0.04 & 0.04 & 0.03 & 0.03 & 0.03 & 0.00 & 0.00 & 0.00 & 0.00 & 0.00 & 0.00 \\
\hline 12 & Manila, Philippines & $14.585^{\circ} \mathrm{N}, 120.968^{\circ} \mathrm{E}$ & 0.08 & 0.08 & 0.07 & 0.07 & 0.07 & 0.07 & -0.04 & -0.04 & -0.04 & -0.04 & -0.04 & -0.04 \\
\hline 13 & Legaspi, Philippines & $13.15^{\circ} \mathrm{N}, 123.75^{\circ} \mathrm{E}$ & 0.06 & 0.06 & 0.06 & 0.06 & 0.06 & 0.06 & 0.01 & 0.01 & 0.01 & 0.01 & 0.01 & 0.01 \\
\hline 14 & Hong Kong, China & $22.3^{\circ} \mathrm{N}, 114.2^{\circ} \mathrm{E}$ & 0.18 & 0.18 & 0.18 & 0.18 & 0.18 & 0.18 & -0.08 & -0.09 & -0.09 & -0.09 & -0.10 & -0.10 \\
\hline 15 & Qui Nhon, Viet Nam & $13.775^{\circ} \mathrm{N}, 109.255^{\circ} \mathrm{E}$ & 0.08 & 0.08 & 0.08 & 0.08 & 0.08 & 0.08 & -0.02 & -0.02 & -0.02 & -0.03 & -0.03 & -0.03 \\
\hline 16 & Vung Tau, Viet Nam & $10.34^{\circ} \mathrm{N}, 107.072^{\circ} \mathrm{E}$ & 0.33 & 0.33 & 0.32 & 0.33 & 0.32 & 0.32 & 0.00 & 0.00 & -0.01 & -0.01 & -0.02 & -0.02 \\
\hline 17 & Ko Lak, Thailand & $11.795^{\circ} \mathrm{N}, 99.817^{\circ} \mathrm{E}$ & 0.17 & 0.16 & 0.16 & 0.19 & 0.18 & 0.19 & -0.03 & -0.02 & -0.04 & -0.07 & -0.07 & -0.08 \\
\hline 18 & Ko Taphao Noi, Thailand & $7.832^{\circ} \mathrm{N}, 98.425^{\circ} \mathrm{E}$ & 0.17 & 0.17 & 0.17 & 0.17 & 0.17 & 0.17 & 0.00 & 0.00 & 0.00 & 0.00 & 0.00 & 0.01 \\
\hline 19 & Pulau Langkawi, Malaysia & $6.432^{\circ} \mathrm{N}, 99.765^{\circ} \mathrm{E}$ & 0.29 & 0.27 & 0.27 & 0.26 & 0.26 & 0.25 & -0.05 & -0.04 & -0.03 & -0.03 & -0.03 & -0.02 \\
\hline \multicolumn{3}{|c|}{ Mean values } & 0.14 & 0.14 & 0.14 & 0.14 & 0.14 & 0.14 & 0.00 & 0.00 & 0.00 & 0.00 & 0.00 & 0.00 \\
\hline
\end{tabular}

rather than instantaneous profile or higher vertical mixing in the model may be one of the possible reasons for this discrepancy. Larger temperature differences at the thermocline region have led to a warm temperature bias in the model forecast (Table 5). Maximum temperature bias and RMSD are 1.95 and $2.96{ }^{\circ} \mathrm{C}$, respectively. Meanwhile, the correlation between the model forecast and observation is above the $99 \%$ confidence level $(r>0.47)$ across all forecast lead times.

Argo and XBT profiles available for the period 1 October to 5 November 2019 are compared with the model forecast to derive the RMSD statistics for temperature and salinity. Since no temperature or salinity profiles are available in the SCS (figure not shown, data distribution can be viewed from http://www.coriolis.eu.org/ Data-Products/Data-Delivery/Data-selection, last access: 6
November 2020), the analysis mainly demonstrates the model performance in the domain excluding the SCS region. As observed in the $\mathrm{M}_{1}$ mooring location, warm biases with varying magnitude are seen in the thermocline region across the analysis domain (figures not shown). Considering the depth range where this bias exists, the vertical mixing parameterisation may have a stronger influence in modifying the thermal stratification than the penetrative shortwave forcing. Statistics of RMSD for ocean temperature and salinity relative to all profile observations are given in Table 6. RMSD of individual profiles are first computed and then a root-meansquare (rms) value of the computed RMSD is derived. RMSD across all forecast lead times and with the number of profiles analysed are listed. For both temperature and salinity, the RMSD remains fairly similar during the entire analysis period. Over the analysis domain and across all forecast lead 
(a) SST $M_{1}\left(5^{\circ} S, 95^{\circ} \mathrm{E}\right)$

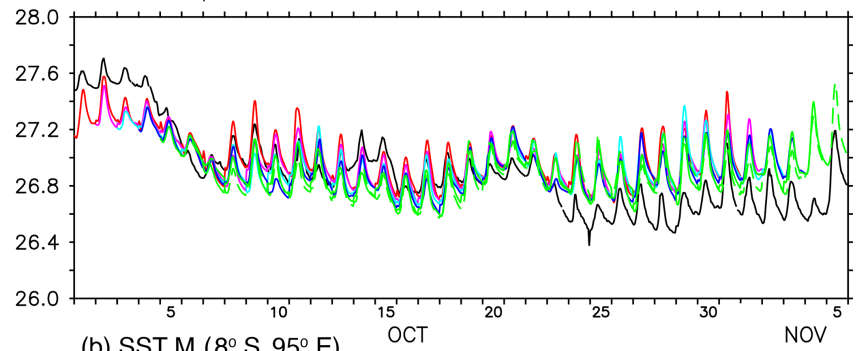

(b) SST $\mathrm{M}_{2}\left(8^{\circ} \mathrm{S}, 95^{\circ} \mathrm{E}\right)$

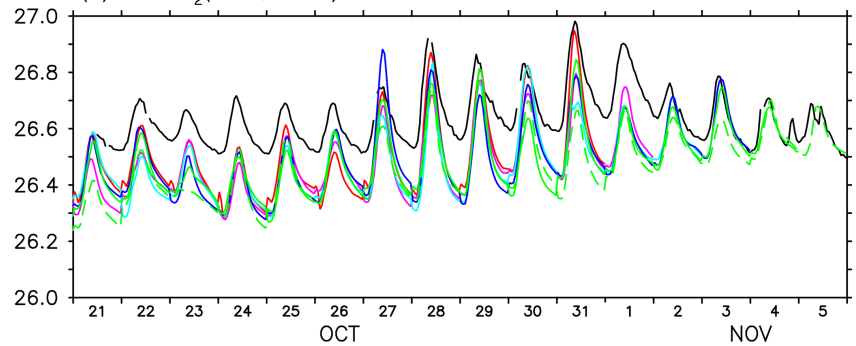

(c) TSG Temp $(z=6.4 \mathrm{~m})$

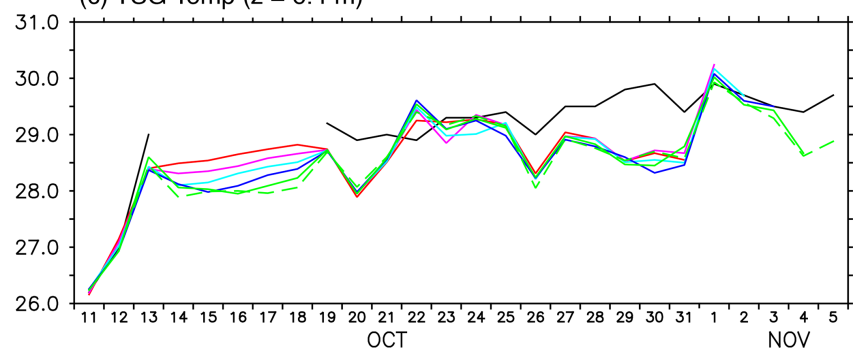

Figure 8. (a, b) Time series of hourly mean SST from model forecast and observations at the locations $\mathrm{M}_{1}\left(5^{\circ} \mathrm{S}, 95^{\circ} \mathrm{E}\right)$ and $\mathrm{M}_{2}\left(8^{\circ} \mathrm{S}, 95^{\circ} \mathrm{E}\right)$. Buoy locations are shown in Fig. 3. (c) Subsurface temperature at $6.4 \mathrm{~m}$ depth for track shown in Fig. 3 from TSG and model: observations (black line), fcst_day1 (red line), fcst_day2 (purple line), fcst_day3 (light blue line), fcst_day4 (blue line), fcst_day5 (green line), and fcst_day6 (dashed green line).

times, the maximum RMSD for temperature and salinity are $1.41^{\circ} \mathrm{C}$ and $0.14 \mathrm{psu}$, respectively. Overall, the model forecast deviation relative to the observations is within acceptable error limits of operational forecast models (e.g. Zhang et al., 2010; Yang et al., 2016).

\subsubsection{Sea surface height}

The same set of tide gauge stations used for the MCO hindcast validation has been employed for $\mathrm{MCO}_{\mathrm{ao}} \mathrm{SSH}$ forecast evaluation. Due to irregularities in the time series, the Currimao Ilocos Norte station is not included in the analysis. Hourly instantaneous SSH data from the model forecast and tide gauge observations are used for the statistical analysis. A summary of SSH RMSD and bias statistics relative to the observations is listed in Table 7. Time series of hourly instantaneous SSH at randomly selected tide gauge stations (Sibolga, Prigi and Vung Tau) and the $\mathrm{MCO}_{\mathrm{ao}}$ forecast (fcst_day1) are plotted in Fig. 10. Model SSH bias is within $\pm 0.10 \mathrm{~m}$ at all tide gauge stations and forecast lead times. The SSH bias is within $\pm 0.05 \mathrm{~m}$ for 14 of total 19 tide gauge stations across all forecast lead times. Since the tide gauges are mostly located near to the coast, SSH variability shorter than intra-seasonal timescale may be largely driven by the tidal forcing. Eventually, in the SSH bias there will be an offset between high and low tidal peaks. Hence, RMSD will give a better representation of model accuracy in tide-dominated regions. RMSD above $0.15 \mathrm{~m}$ is observed at the tide gauge stations in Hong Kong $(0.18 \mathrm{~m})$, Vung Tau $(0.33 \mathrm{~m})$, Ko Lak $(0.19 \mathrm{~m})$, Ko Taphao Noi $(0.17 \mathrm{~m})$, and Pulau Langkawi $(0.29 \mathrm{~m})$. The SDs of SSH observations at these stations during October 2019 are 0.46, 0.82, 0.40, 0.71, and $0.73 \mathrm{~m}$, respectively, and the model forecast error is low relative to the observed SD. No significant variation in model forecast accuracy or RMSD is seen with the increase in forecast lead time. The SSH RMSD is less than $0.10 \mathrm{~m}$ for 13 of the total 19 tide gauge stations across all forecast lead times. Overall, the model-simulated SSH shows good agreement with the observations.

\section{Summary and future developments}

The Maritime Continent has a profound influence on the global climate system because of its complex topography and unique geographic location within the tropical IndoPacific warm pool. The MC region is characterised by strong atmosphere-ocean coupled processes across multiple timescales. A coupled convective-scale, eddy-resolving atmosphere-ocean modelling system for the western MC, described in T18, was able to improve the simulation of a cold-surge event, the intensity of Typhoon Sarika, and its atmosphere-ocean interactions. Several upgrades have been added to the T18 model for a future operational implementation, such as extending the eastern boundary of the model domain to the western Pacific Ocean, improved science configuration of the atmospheric model (MetUM), and incorporation of tidal boundary forcing to the ocean model (NEMO). Furthermore, the coupled model's feasibility for use as an operational forecast system is also being tested. Typical runtimes of the daily forecast simulations in our experiments are found to be suitable for the operational forecast applications.

The $\mathrm{MC}_{\mathrm{ao}}$ coupled prediction system was run as a preoperational forecast system from 1 to 31 October 2019. Hindcast simulations performed for the period 1 January 2014 to 30 September 2019, using the uncoupled ocean model $\mathrm{MCO}$, provided the initial condition to the $\mathrm{MCO}_{\mathrm{ao}}$. This paper presents details of an atmosphere-ocean coupled prediction system developed for the MC and evaluations of oceanonly model hindcasts and $6 \mathrm{~d}$ ocean forecast simulations performed using the coupled system.

The evaluation of MCO hindcast is intended to understand the model's performance in reproducing the past ocean variability, particularly at the ocean surface where the exchange 
(a) Mooring $\mathrm{M}_{1}\left(5^{\circ} \mathrm{S}, 95^{\circ} \mathrm{E}\right)$

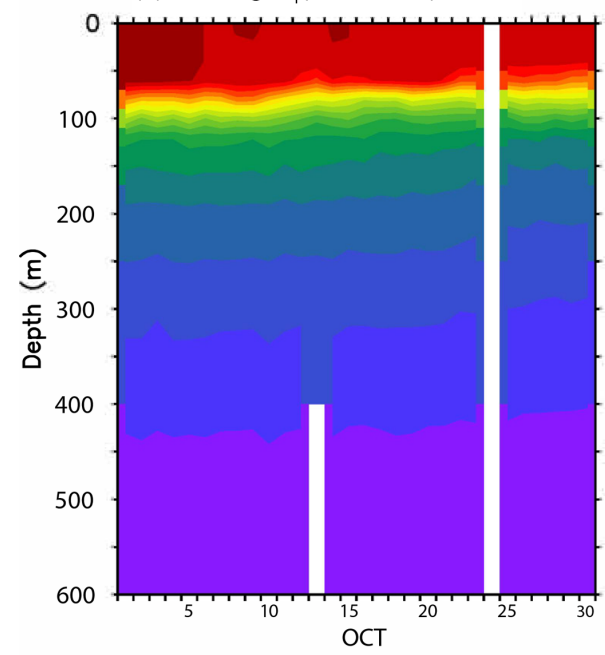

(c) $\mathrm{MCO}_{\mathrm{ao}}$ FCST DAY $3\left(5^{\circ} \mathrm{S}, 95^{\circ} \mathrm{E}\right)$

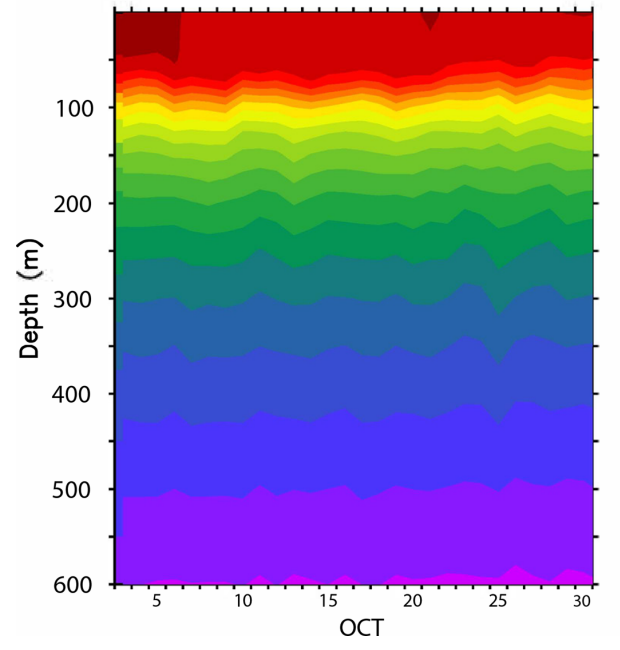

(b) $\mathrm{MCO}_{\mathrm{a} 0}$ FCST DAY $1\left(5^{\circ} \mathrm{S}, 95^{\circ} \mathrm{E}\right)$

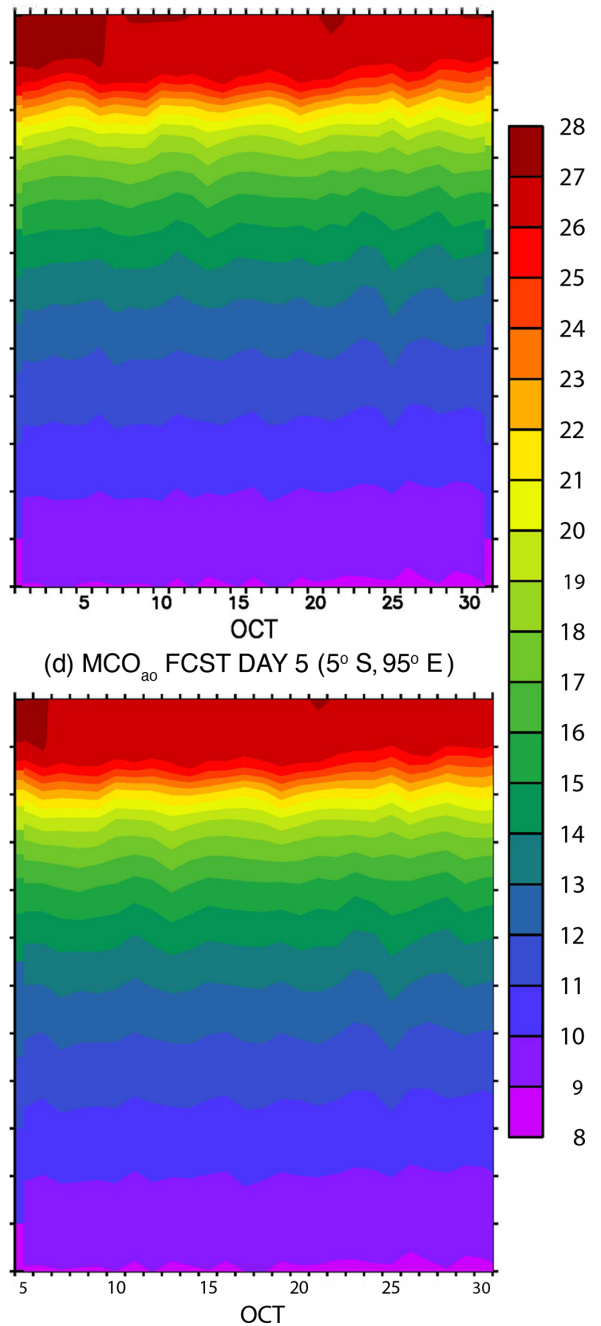

Figure 9. Depth-time plots of temperature $\left({ }^{\circ} \mathrm{C}\right)$ at the $\mathrm{M}_{1}$ mooring location from (a) buoy observations and model forecast (b) fcst_day1, (c) fcst_day3, and (d) fcst_day5. The $x$ axis starting date is different between (c) and (d).

of fluxes between the atmosphere and ocean takes place. The ERA5-driven simulations during the period from 1 January 2018 to 30 June 2019 are utilised for the evaluation of MCO. The SST RMSD between the model hindcast and OSTIA is less than $0.5^{\circ} \mathrm{C}$ for about $97 \%$ of the analysis domain. Their correlation is above the $99.9 \%$ confidence level, with about $88 \%$ of the analysis domain displaying correlation higher than 0.8. An SST cold bias is seen in the Andaman Sea, while most of the South China Sea, equatorial western Pacific Ocean, and Australian coast of the Timor Sea show a warm bias. Overall, the mean SST bias, RMSD, and mean correlation over the domain are $0.07^{\circ} \mathrm{C}, 0.34^{\circ} \mathrm{C}$, and 0.90 , respectively.

Comparison of model SST with the RAMA moored buoy observations located at the southeastern tropical Indian Ocean shows good agreement. The SST bias, RMSD, and correlation coefficient between the model and obser- vation are $0.17^{\circ} \mathrm{C}, 0.29^{\circ} \mathrm{C}$, and 0.94 , respectively, for $\mathrm{M}_{1}$ and $0.12^{\circ} \mathrm{C}, 0.41^{\circ} \mathrm{C}$, and 0.92 , respectively, for $\mathrm{M}_{2}$ locations. The SSH RMSD is less than $0.10 \mathrm{~m}$ for 18 of total 20 tide gauge stations analysed, and 14 stations show RMSD less than $0.05 \mathrm{~m}$. Comparison of model-simulated SST and SSH fields show good agreement with observation and analysis data. Statistically significant correlation with observation suggests that both the spatial and temporal patterns of variability are reasonably well reproduced by the model.

For the evaluation of $\mathrm{MCO}_{\mathrm{ao}}$, comparisons of ocean forecast for different forecast lead times with OSTIA SST and in situ observations have been performed. The forecasted SST over most of the sub-regions is within the error standard deviation of the OSTIA. Though the model forecast exhibits a warm SST bias, the RMSD is less than $0.45^{\circ} \mathrm{C}$ over most of the sub-regions during the analysis period. Generally, the forecasted SST tends to be cooler with an increase in forecast 
(a) Sibolga, Indonesia

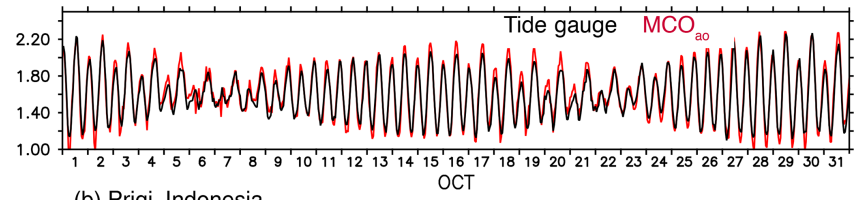

(b) Prigi, Indonesia

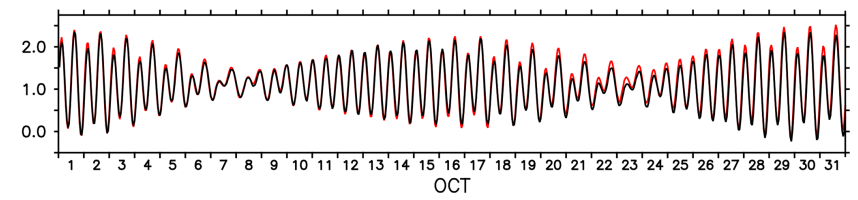

(c) Vung Tau, Viet Nam

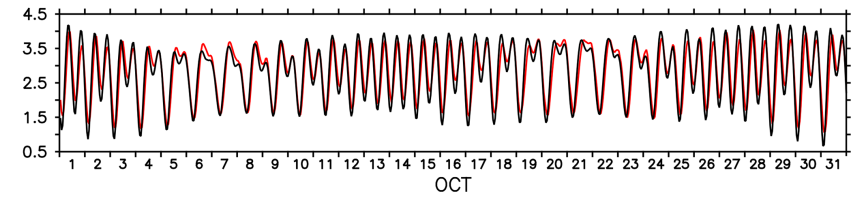

Figure 10. Time series of hourly instantaneous SSH (in metres) from tide gauge observations (black line) and a $\mathrm{MCO}_{\mathrm{ao}}$ forecast lead time of $1 \mathrm{~d}$ (fcst_day1, red line) at randomly selected stations, (a) Sibolga $\left(1.75^{\circ} \mathrm{N}, 98.767^{\circ} \mathrm{E}\right)$, (b) Prigi $\left(8.28^{\circ} \mathrm{S}, 111.73^{\circ} \mathrm{E}\right)$, and (c) Vung Tau $\left(10.34^{\circ} \mathrm{N}, 107.072^{\circ} \mathrm{E}\right)$, during October 2019.

lead time, denoting a lower warm bias and RMSD relative to fcst_day1. Overall, the SST correlation over the analysis domain is above the $99 \%$ confidence level across all forecast lead times, while the bias and RMSD are less than 0.19 and $0.35^{\circ} \mathrm{C}$, respectively.

The diurnal variability of SST at the RAMA moored buoy locations $\mathrm{M}_{1}$ and $\mathrm{M}_{2}$ are reasonably well reproduced by the model across all forecast lead times. SST bias and RMSD at $\mathrm{M}_{1}$ are less than 0.0 and $0.20^{\circ} \mathrm{C}$, respectively, and remains fairly constant across all forecast lead times. Meanwhile, the RMSD at $\mathrm{M}_{2}$ is relatively low, with a maximum of $0.18^{\circ} \mathrm{C}$ across all forecast lead times. The depth of the upper ocean isothermal and mixed layer at the $M_{1}$ is well forecasted by the model. To understand the model skill in predicting subsurface temperature and salinity, in situ profile observations are compared with the model forecast for different forecast lead times. For both temperature and salinity, the RMSD remains fairly constant during the entire analysis period.

Comparison of model-forecasted SSH shows good agreement with the tide gauge observations. About $75 \%$ of the stations show bias within $\pm 0.05 \mathrm{~m}$ at all forecast lead times. No significant variation in model forecast accuracy or RMSD is seen with the increase in forecast lead time. About $73 \%$ of total stations show RMSD less than $0.10 \mathrm{~m}$ for all forecast lead times. Overall, the model forecast deviation of SST, $\mathrm{SSH}$, and subsurface temperature and salinity fields relative to observation is within acceptable error limits of operational forecast models (e.g. Zhang et al., 2010; Yang et al., 2016).

Analysis of subsurface fields revealed that significant model temperature biases exist in the region below the mixed layer. The representation of stratification in the thermocline region is relatively weak in the model forecast than the observations. This subsurface temperature bias remains across the model domain with varying magnitudes. Similar temperature biases were reported earlier in simulations with identical model configurations (e.g. Graham et al., 2018). Further modelling work is needed to improve the thermal stratification through fine-tuning the mixing coefficients or modifying the vertical mixing parameterisation.

Further analysis of model forecast fields using longer forecast simulations with increased observations will be undertaken to assess the model predictability across different seasons and during typical weather events such as a cold surge, a typhoon, or the MJO. In addition, the impact of coupling on the forecast will be investigated by performing simultaneous stand-alone ocean model forecast simulations. In addition, work is ongoing to improve our understanding of the forecast skill of $\mathrm{MCA}_{\mathrm{ao}}$, and results from that analysis will be presented as research publications (Kumar et al., 2021). The analysis of model-forecasted precipitation, surface wind, pressure, relative humidity, etc., will be undertaken. The comparisons of coupled and atmosphere-only forecasts will also be performed in that study.

The evaluation of sea surface salinity and ocean current fields is not included in the present study mainly due to the lack of in situ and satellite observations. The South China Sea remains as an especially data-sparse region in terms of the subsurface observations, which highlights the necessity of coordinated efforts from the scientific community to fill these spatial data gaps.

In our analyses, the RMSD and positive or negative biases of the ocean forecasts are generally comparable to those observed from the hindcast statistics. This suggests that, up to a certain extent, the model forecast deviation is inherited from the MCO hindcast or the $\mathrm{MCO}_{\mathrm{ao}}$ initial condition. The dependency of model forecast quality on the initial state is well established in the numerical weather prediction studies. Over the tropical oceans specifically, the initialisation of the ocean state is an important element of the forecast systems. The data assimilation techniques help to acquire an improved estimate of the ocean state by combining the modelsimulated fields and observations (King et al., 2018). Both the uncoupled and coupled ocean configurations used in our study are free-running models with no restoring or relaxation to the real world. Hence, to provide a better initial condition to $\mathrm{MCO}_{\mathrm{ao}}$, implementation of data assimilation capability for MCO will be a key priority in our future developments. In addition, earlier studies have shown that including waveinduced mixing in ocean circulation model yields a better representation of the upper-ocean temperature (Lewis et al., 2019b). Thus, work towards the development of a three-way atmosphere-ocean-wave coupled system will be undertaken in the future. 
Code and data availability. Due to intellectual property right restrictions, the coupled model system, MetUM and JULES source code, and documentation cannot be provided directly.

Obtaining the MetUM. The Met Office Unified Model is available for use under license from UK Met Office via a shared MetUM code repository, which can be accessed via https://code.metoffice. gov.uk/trac/um/wiki (Met Office, 2021). A number of research organisations and national meteorological services use the UM in collaboration with the Met Office to undertake basic atmospheric process research, produce forecasts, develop the UM code, and build and evaluate Earth system models. For further information on how to apply for a license, see http://www.metoffice.gov.uk/research/ modelling-systems/unified-model (last access: 15 February 2021).

Obtaining JULES. JULES is available free of charge under license. For further information on how to gain permission to use JULES for research purposes, see http://jules-1sm.github.io/access_ req/JULES_access.html (last access: 15 February 2021).

Obtaining NEMO. The NEMO v3.6 model code and documentation are freely available from the NEMO website (https://www. nemo-ocean.eu, last access: 17 February 2021, Madec et al., 2016). The details of NEMO branches, compilation keys, and namelist parameters used in our modelling systems are described in the Supplement.

Obtaining OASIS-MCT. The OASIS3-MCT coupler is disseminated to registered users as free software from https://verc.enes.org/ oasis (last access: 15 February 2021, Valcke, 2013).

Data. The data size of coupled forecast model output in our simulations is of several terabytes and requires a large storage facility. However, all model outputs analysed in the paper can be made available upon contacting the authors. The observational datasets used for the model evaluation are freely available, and the data sources are described in Sect. 3 of the paper.

Supplement. The supplement related to this article is available online at: https://doi.org/10.5194/gmd-14-1081-2021-supplement.

Author contributions. BT and CS developed the coupled modelling system. BT performed model simulations, analysed data, and wrote the paper with input from CS and RK. BCPH and RK contributed to the coupled system development. JL provided system and software support to the study. XYH and PT performed funding acquisition and provided supervision. $\mathrm{BCPH}, \mathrm{JL}, \mathrm{XYH}$, and PT contributed to the discussion and improvement of the paper.

Competing interests. The authors declare that they have no conflict of interest.

Acknowledgements. The model simulations are performed in the Cray XC-30 HPC system housed at CCRS. We acknowledge Christopher Gordon, Huw Lewis, Enda O'Dea, Juan Manuel Castillo, and Jennifer Graham for their scientific and technical support. We acknowledge ECMWF, Copernicus Marine Environment Monitoring Service, Coriolis, UHSLC, and Aviso for various datasets used in the study. Figures are drawn using Ferret and Python software. We gratefully acknowledge three anonymous re- viewers, Joao Souza, and the executive editor Astrid Kerkweg for their comments on the discussion paper, which helped to improve the paper.

Financial support. The project is funded by the National Environmental Agency, Singapore, through the Meteorological Service Singapore as a collaborative research between the Centre for Climate Research Singapore (CCRS) and the National University of Singapore (NUS).

Review statement. This paper was edited by Rohitash Chandra and reviewed by three anonymous referees.

\section{References}

Abel, S. J. and Boutle, I. A.: An improved representation of the raindrop size distribution for single-moment microphysics schemes, Q. J. Roy. Meteor. Soc., 138, 2151-2162, 2012.

Aldrian, E., Sein, D. V., Jacob, D., Gates, L. D., and Podzun, R.: Modeling Indonesian rainfall with a coupled regional model, Clim. Dynam., 25, 1-17, 2005.

Aranami, K., Davies, T., and Wood, N.: A mass restoration scheme for limited-area models with semi-Lagrangian advection, Q. J. Roy. Meteor. Soc., 141, 1795-1803, 2015.

Best, M. J., Pryor, M., Clark, D. B., Rooney, G. G., Essery, R. L. H., Ménard, C. B., Edwards, J. M., Hendry, M. A., Porson, A., Gedney, N., Mercado, L. M., Sitch, S., Blyth, E., Boucher, O., Cox, P. M., Grimmond, C. S. B., and Harding, R. J.: The Joint UK Land Environment Simulator (JULES), model description Part 1: Energy and water fluxes, Geosci. Model Dev., 4, 677-699, https://doi.org/10.5194/gmd-4-677-2011, 2011.

Birch, C. E., Parker, D. J., Marsham, J. H., Copsey, D., and GarciaCarreras, L.: A seamless assessment of the role of convection in the water cycle of the West African Monsoon, J. Geophys. Res.Atmos., 119, 2890-2912, 2014.

Birch, C. E., Webster, S., Peatman, S. C., Parker, D. J., Matthews, A. J., Li, Y., and Hassim, M. E.: Scale interactions between the MJO and the western Maritime Continent, J. Climate, 29, 2471-2492, 2016.

Bjerknes, J.: Atmospheric teleconnections from the equatorial Pacific, Mon. Weather Rev., 97, 163-172, https://doi.org/10.1175/15200493(1969)097<0163:ATFTEP>2.3.CO;2, 1969.

Boutle, I. A., Eyre., J. E. J., and Lock, A. P.: Seamless stratocumulus simulation across the turbulent gray zone, Mon. Weather Rev., 142, 1655-1668, 2014.

Bush, M., Allen, T., Bain, C., Boutle, I., Edwards, J., Finnenkoetter, A., Franklin, C., Hanley, K., Lean, H., Lock, A., Manners, J., Mittermaier, M., Morcrette, C., North, R., Petch, J., Short, C., Vosper, S., Walters, D., Webster, S., Weeks, M., Wilkinson, J., Wood, N., and Zerroukat, M.: The first Met Office Unified Model-JULES Regional Atmosphere and Land configuration, RAL1, Geosci. Model Dev., 13, 1999-2029, https://doi.org/10.5194/gmd-13-1999-2020, 2020.

Caldwell, P. C., Merrifield, M. A., and Thompson, P. R.: Sea level measured by tide gauges from global oceans - the Joint Archive 
for Sea Level holdings (NCEI Accession 0019568), Version 5.5, NOAA National Centers for Environmental Information, Dataset, https://doi.org/10.7289/V5V40S7W, 2015.

Canuto, V., Howard, A., Cheng, Y., and Dubovikov, M.: Ocean turbulence, Part I: One-point closure model-momentum and heat vertical diffusivities, J. Phys. Oceanogr., 31, 1413-1426, 2001.

Dai, A. and Trenberth, K. E.: Estimates of freshwater discharge from continents: Latitudinal and seasonal variations, J. Hydrometeorol., 3, 660-687, 2002.

Davies, H.: A lateral boundary formulation for multi-level prediction models, Q. J. Roy. Meteor. Soc., 102, 405-418, 1976.

Dipankar, A., Webster, S., Sun, X., Sanchez, C., North, R., Furtado, K., Wilkinson, J., Lock, A., Vosper, S., Huang, X.-Y., and Barker, D.: SINGV: a convective-scale weather forecast model for Singapore, Q. J. Roy. Meteor. Soc., 146, 4131-4146, https://doi.org/10.1002/qj.3895, 2020.

Donlon, C. J., Martin, M., Stark, J. D., Roberts-Jones, J., Fiedler, E., and Wimmer, W.: The Operational sea surface temperature and sea ice analysis (OSTIA), Remote Sens. Environ., 116, 140-158, https://doi.org/10.1016/j.rse.2010.10.017, 2012.

Edwards, J. M. and Slingo, A.: Studies with a flexible new radiation code, I: Choosing a configuration for a largescale model, Q. J. Roy. Meteor. Soc., 122, 689-719, https://doi.org/10.1002/qj.49712253107, 1996.

Flather, R. A.: A tidal model of the northwest European continental shelf, Mem. Soc. R. Sci. Liege, 10, 141-164, 1976.

Giorgi, F. and Gutowski Jr., W. J.: Regional dynamical downscaling and the CORDEX initiative, Ann. Rev. Env. Res., 40, 467-490, 2015.

Graham, J. A., O’Dea, E., Holt, J., Polton, J., Hewitt, H. T., Furner, R., Guihou, K., Brereton, A., Arnold, A., Wakelin, S., Castillo Sanchez, J. M., and Mayorga Adame, C. G.: AMM15: a new high-resolution NEMO configuration for operational simulation of the European north-west shelf, Geosci. Model Dev., 11, 681696, https://doi.org/10.5194/gmd-11-681-2018, 2018.

Gvirtzman, Z. and Stern, R. J.: Bathymetry of Mariana trencharc system and formation of the Challenger Deep as a consequence of weak plate coupling, Tectonics, 23, TC2011, https://doi.org/10.1029/2003TC001581, 2004.

Hersbach, H., Bell, B., Berrisford, P., Hirahara, S., Horányi, A., Muñoz-Sabater, J., Nicolas, J., Peubey, C., Radu, R., Schepers, D., Simmons, A., Soci, C., Abdalla, S., Abellan, X., Balsamo, G., Bechtold, P., Biavati, G., Bidlot, J., Bonavita, M., De Chiara, G., Dahlgren, P., Dee, D., Diamantakis, M., Dragani, R., Flemming, J., and Forbes, R: The ERA5 global reanalysis, Q. J. Roy. Meteor. Soc., 146, 1999-2049, https://doi.org/10.1002/qj.3803, 2020.

Huang, X.-Y., Barker, D., Webster, S., Dipankar, A., Lock, A., Mittermaier, M., Sun, X. M., North, R., Darvell, R., Boyd, D., Lo, J., Liu, J. Y., Macpherson, B., Heng, P., Maycock, A., Pitcher, L., Tubbs, R., McMillan, M., Zhang, S. J., Hagelin, S., Porson, A., Song, G. T., Beckett, B., Cheong, W. K., Semple, A., and Gordon, C.: SINGV - the convective-scale numerical weather prediction system for Singapore, ASEAN J. Sci. Tech. Dev., 36, 81-90, 2019.

King, R. R., While, J., Martin, M. J., Lea, D. J., Lemieux-Dudon, B., Waters, J., and O'Dea, E.: Improving the initialisation of the Met Office operational shelf-seas model, Ocean. Modell., 130, 1-14, https://doi.org/10.1016/j.ocemod.2018.07.004, 2018.
Kumar, R., Sanchez, C., Heng, B. C. P., Thompson, B., Liu, J., Huang, X.-Y., and Tkalich, P.: Development of a MetUM (v 11.1) and NEMO (v 3.6) coupled operational forecast model for the Maritime Continent - Part 2: Evaluation of Atmospheric Forecasts, in preparation, 2021.

Large, W. G. and Yeager, S.: Diurnal to decadal global forcing for ocean and sea-ice models: the data sets and flux climatologies, NCAR Technical Note, NCAR/TN-460 STR, CGD Division of the National Center for Atmospheric Research, Boulder, USA, 105 pp., 2004.

Lee, T.-C., Knutson, T. R., Nakaegawa, T., Ying, M., and Cha, E. M.: Third assessment on impacts of climate change on tropical cyclones in the Typhoon Committee Region - Part I: Observed changes, detection and attribution, Tropical Cyclone Res. Rev., 9, 1-22, 2020.

Lellouche, J.-M., Greiner, E., Le Galloudec, O., Garric, G., Regnier, C., Drevillon, M., Benkiran, M., Testut, C.-E., BourdalleBadie, R., Gasparin, F., Hernandez, O., Levier, B., Drillet, Y., Remy, E., and Le Traon, P.-Y.: Recent updates to the Copernicus Marine Service global ocean monitoring and forecasting realtime $1 / 12^{\circ}$ high-resolution system, Ocean Sci., 14, 1093-1126, https://doi.org/10.5194/os-14-1093-2018, 2018.

Lengaigne, M., Menkes, C., Aumont, O., Gorgues, T., Bopp, L., and Madec, J: Bio-physical feedbacks on the tropical pacific climate in a coupled general circulation model, Clim. Dynam., 28, 503516, 2007.

Levier, B., Tréguier, A. M., Madec, G., and Garnier, V.: Free surface and variable volume in the NEMO code, Tech. rep., MERSEA MERSEA IP report WP09-CNRS-STR-03-1A, 47 pp., 2007.

Lewis, H. W., Castillo Sanchez, J. M., Graham, J., Saulter, A., Bornemann, J., Arnold, A., Fallmann, J., Harris, C., Pearson, D., Ramsdale, S., Martínez-de la Torre, A., Bricheno, L., Blyth, E., Bell, V. A., Davies, H., Marthews, T. R., O’Neill, C., Rumbold, H., O’Dea, E., Brereton, A., Guihou, K., Hines, A., Butenschon, M., Dadson, S. J., Palmer, T., Holt, J., Reynard, N., Best, M., Edwards, J., and Siddorn, J.: The UKC2 regional coupled environmental prediction system, Geosci. Model Dev., 11, 1-42, https://doi.org/10.5194/gmd-11-1-2018, 2018.

Lewis, H. W., Castillo Sanchez, J. M., Arnold, A., Fallmann, J., Saulter, A., Graham, J., Bush, M., Siddorn, J., Palmer, T., Lock, A., Edwards, J., Bricheno, L., Martínez-de la Torre, A., and Clark, J.: The UKC3 regional coupled environmental prediction system, Geosci. Model Dev., 12, 2357-2400, https://doi.org/10.5194/gmd-12-2357-2019, 2019a.

Lewis, H. W., Castillo Sanchez, J. M., Siddorn, J., King, R. R., Tonani, M., Saulter, A., Sykes, P., Pequignet, A.-C., Weedon, G. P., Palmer, T., Staneva, J., and Bricheno, L.: Can wave coupling improve operational regional ocean forecasts for the north-west European Shelf?, Ocean Sci., 15, 669-690, https://doi.org/10.5194/os-15-669-2019, 2019b.

Li, Y., Jourdain, N. C., Taschetto, A. S., Gupta, A. S., Argüeso, D., Masson, S., and Cai, W.: Resolution dependence of the simulated precipitation and diurnal cycle over the Maritime Continent, Clim. Dynam., 48, 4009-4028, 2017.

Li, Y., Peng, S., Wang, J., and Yan, J.: Impacts of nonbreaking wave-stirring-induced mixing on the upper ocean thermal structure and typhoon intensity in the South China Sea, J. Geophys. Res.-Oceans, 119, 5052-5070, https://doi.org/10.1002/2014JC009956, 2014. 
Lilly, D. K.: On the numerical simulation of buoyant convection, Tellus A, 14, 148-172, https://doi.org/10.3402/tellusa.v14i2.9537, 1962.

Ling, Z., Wang, G., Wang, C., and Fan, Z.-S.: Different effects of tropical cyclones generated in the South China Sea and the northwest Pacific on the summer South China Sea circulation, J. Oceanogr., 67, 347-355, 2011.

Lock, A. P., Brown, A. R., Bush, M. R., Martin, G. M., and Smith, R. N. B.: A new boundary layer mixing scheme, Part I: Scheme description and SCM tests, Mon. Weather Rev., 128, 3187-3199, 2001

Love, B. S., Matthews, A. J., and Lister, G. M. S.: The diurnal cycle of precipitation over the Maritime Continent in a high resolution atmospheric model, Q. J. Roy. Meteor. Soc., 137, 934-947, 2011.

Lyard, F., Lefèvre, F., Letellier, T., and Francis O.: Modelling the global ocean tides: modern insights from FES2004, Ocean Dynam., 56, 394-415, 2006.

Madden, R. A. and Julian, P. R.: Observations of the 40-50-day tropical oscillation - a review, Mon. Weather Rev., 122, 814 837, 1994

Madec, G. and the NEMO team: NEMO reference manual 3_6_STABLE:NEMO ocean engine, Note du Pôle de modélisation, Institut Pierre-Simon Laplace (IPSL), France, No. 27, ISSN 1288-1619, 2016.

Manners, J., Vosper, S. B., and Roberts, N.: Radiative transfer over resolved topographic features for high resolution weather prediction, Q. J. Roy. Meteor. Soc., 138, 720-733, 2011.

McPhaden, M. J., Meyers, G., Ando, K., Masumoto, Y., Murty, V. S. N., Ravichandran, M., Syamsudin, F., Vialard, J., Yu, L., and Yu, W.: RAMA: The Research Moored Array for African-AsianAustralian Monsoon Analysis and Prediction, B. Am. Meteorol. Soc., 90, 459-480, https://doi.org/10.1175/2008BAMS2608.1, 2009.

Meehl, G. A.: Development of global coupled ocean-atmosphere general circulation models, Clim. Dynam., 5, 19-33, 1990.

Met Office: available at: https://code.metoffice.gov.uk/trac/um/ wiki, last access: 15 February 2021.

Miller, A. J., Collins, M., Gualdi, S., Jensen, T. G., Misra, V., Pezzi, L. P., Pierce, D. W., Putrasahan, D., Seo, H., and Tseng, Y. H.: Coupled ocean-atmosphere modeling and predictions, J. Mar. Res., 75, 361-402, https://doi.10.1357/002224017821836770, 2017.

Neale, R. and Slingo, J.: The Maritime Continent and its role in the global climate: a GCM study, J. Climate, 16, 834-848, 2003.

Qu, T., Du, Y., Strachan, J., Meyers, G., and Slingo, J.: Sea surface temperature and its variability in the Indonesian region, Oceanography, 18, 50-61, 2005.

Saji, N. H., Goswami, B. N., Vinayachandran, P. N., and Yamagata, T.: A dipole mode in the tropical Indian Ocean, Nature, 401, 360363,1999

Siddorn, J. R. and Furner, R.: An analytical stretching function that combines the best attributes of geopotential and terrain-following vertical coordinates, Ocean. Model., 66, 1-3, 2013.

Smith, R. N. B.: A scheme for predicting layer cloud and their water content in a general circulation model, Q. J. Roy. Meteor. Soc., 116, 435-460, https://doi.org/10.1002/qj.49711649210, 1990.
St. Laurent, L., Simmons, H., and Jayne, S.: Estimating tidally driven mixing in the deep ocean, Geophys. Res. Lett., 29, 2106, https://doi.org/10.1029/2002G L015633, 2002.

Thompson, B., Sanchez, C., Sun, X., Song, G., Liu, J., Huang, X.Y., and Tkalich, P.: A high-resolution atmosphere-ocean coupled model for the western Maritime Continent: development and preliminary assessment, Clim. Dynam., 52, 3951-3981, https://doi.org/10.1007/s00382-018-4367-0, 2018.

Umlauf, L. and Burchard, H.: A generic length-scale equation for geophysical turbulence models, J. Mar. Res., 61, 235-265, 2013.

Valcke, S.: The OASIS3 coupler: a European climate modelling community software, Geosci. Model Dev., 6, 373-388, https://doi.org/10.5194/gmd-6-373-2013, 2013.

Vincent, C. L. and Lane, T. P.: A 10-year austral summer climatology of observed and modeled intraseasonal, mesoscale, and diurnal variations over the Maritime Continent, J. Climate, 30, 3807-3828, https://doi.org/10.1175/JCLI-D-16-0688.1, 2017.

Webster, P. J., Moore, A. M., Loschnigg, J. P., and Leben, R. R.: Coupled ocean-atmosphere dynamics in the Indian Ocean during 1997-98, Nature, 401, 356-360, 1999.

Wei, J., Malanotte-Rizzoli, P., Eltahir, E., Xue, P., Zhang, D., and $\mathrm{Xu}$, D.: Coupling of a regional atmospheric model (RegCM3) and a regional oceanic model (FVCOM) over the Maritime Continent, Clim. Dynam., 43, 1575-1594, 2014.

Wilson, D. R. and Ballard, S. P.: A microphysically based precipitation scheme for the UK meteorological office unified model, Q. J. Roy. Meteor. Soc., 125, 1607-1636, 1999.

Wilson, D. R., Bushell, A. C., Kerr-Munslow, A. M., Price, J. D., and Morcrette, C. J.: PC2: A prognostic cloud fraction and condensation scheme, I: Scheme description, Q. J. Roy. Meteor. Soc., 134, 2093-2107, https://doi.org/10.1002/qj.333, 2008.

Wood, N., Staniforth, A., White, A., Allen, T., Diamantakis, M., Gross, M., Melvin, T., Smith, C., Vosper, S., Zerroukat, M., and Thuburn, J.: An inherently mass-conserving semi-implicit semiLagrangian discretization of the deep-atmosphere global nonhydrostatic equations, Q. J. Roy. Meteor. Soc., 140, 1505-1520, 2014.

Xue, P., Eltahir, E. A. B., Malanotte-Rizzoli, P., and Wei, J.: Local feedback mechanisms of the shallow water region around the Maritime Continent, J. Geophys. Res.-Oceans, 119, 6933-6951, 2014.

Xue, P., Malanotte-Rizzoli, P., Wei, J., and Eltahir, E. A. B.: Coupled ocean-atmosphere modeling over the Maritime Continent: A review, J. Geophys. Res.-Oceans, 125, 2019JC014978, https://doi.org/10.1029/2019JC014978, 2020.

Yang, Z., Richardson, P., Chen, Y., Kelley, J. G. W., Myers, E., Aikman, F. I., Peng, M., and Zhang, A.: Model Development and Hindcast Simulations of NOAA's Gulf of Maine Operational Forecast System, J. Mar. Sci. Eng., 4, 77, https://doi.org/10.3390/jmse4040077, 2016.

Zhang, A., Hess, K. W., and Aikman, F. I.: User-based skill assessment techniques for operational hydrodynamic forecast systems, J. Oper. Oce., 3, 11-24, 2010. 